AperTO - Archivio Istituzionale Open Access dell'Università di Torino

The new paradigm of creativity and innovation and its corollaries for the law of obligations

This is a pre print version of the following article:

Original Citation:

Availability:

This version is available http://hdl.handle.net/2318/1559624

since 2021-04-19T12:25:12Z

Publisher:

Edward Elgar

Terms of use:

Open Access

Anyone can freely access the full text of works made available as "Open Access". Works made available under a Creative Commons license can be used according to the terms and conditions of said license. Use of all other works requires consent of the right holder (author or publisher) if not exempted from copyright protection by the applicable law. 


\section{Marco Ricolfi}

\section{The new paradigm of creativity and innovation and its corollaries for the law of obligations}

\section{THREE CLAIMS AND ONE COROLLARY}

For over three centuries, in our legal systems, the incentive to creativity and technological innovation has been provided by the legal tool of exclusivity. Over that period of time, exclusivity underpinned a paradigm which dominated all the areas of creativity and innovation and shaped each and all intellectual property rights (IPRs) as enshrined in the twin Conventions of Paris (1883) and of Berne (1886): copyrights, patents, as well as trademarks. ${ }^{1}$ However, in the last 20 years the question has arisen whether, in an age in which a great part of novel creations and innovations comes in digital format and network-driven digital platforms

\footnotetext{
1 The point has been made innumerable times; on the role of exclusivity categorized as one of the three 'P's (Property, Procurement and Patronage) which may remedy market failure in the provision of public goods - see the brilliant presentation by P. David, 'Intellectual Property Institutions and the Panda's Thumb: Patents, Copyrights, and Trade Secrets in Economic Theory and History', in M. B. Wallerstein, M. E. Mogee and R. A. Schoen (eds), Global Dimensions of Intellectual Property Rights in Science and Technology, Washington, D.C. (1993) 19, expanded in a later and memorable presentation at the Alessandria University, 'Le istituzioni della proprietà intellettuale e il pollice del Panda: brevetti, diritti d'autore e segreti industriali nella teoria economica e nella storia', in G. Clerico and S. Rizzello (eds), Diritto ed economia della proprietà intellettuale, Padua, (1998) 9, 24, 28. A thorough rethinking of the roles of the three Ps in the current context is to be found in the groundbreaking paper by M. Libertini, 'Funzioni ed ancoraggi apicali della proprietà industriale' forthcoming. The recurring underestimation of the role played by public procurement in innovation is rebutted in two important recent works: M. Mazzuccato, The Entrepreneurial State: Debunking Public vs. Private Sector Myths, London (2013) and W. H. Janeway, Doing Capitalism in the Innovation Economy: Markets, Speculation and the State, Cambridge, (2014).
} 
enable unprecedented forms of cooperation in the production, sharing and dissemination of innovation, the previous exclusivity centered paradigm still is entirely appropriate or, in the alternative, should be revised, amended and complemented. ${ }^{2}$

In this paper I will stake three claims. First, that in our legal systems ${ }^{3}$ the incentive provided by exclusivity is no longer always indispensable to generate the optimal rate of creativity, as the social and technological basis of creativity and innovation have in the meantime dramatically changed (section III). Second, that, while IP exclusivity may still be required to provide an incentive for technological innovation (section IV), the same is apt to systematically backfire even in the technology sector, that is to prove counterproductive in view of the attainment of the optimal rate of generation of novel works and technology (section V). Third, that an entirely new paradigm of creativity and innovation is emerging. In the last connection, I will argue that in this novel paradigm, which for the time being would appear to be called to complement rather than to replace the old exclusivity- and market-exchange-based model, a crucial role is played by digital network-driven cooperation rather than by the incentive provided by exclusivity (section VI). Throughout the paper I will argue that the driving role played by cooperation rather than by the incentive provided by exclusivity is to a large extent accounted for

2 The emergence of sharing as a mode of production and distribution of goods and services and its advantages over price-based market exchanges is now a very well established topos, which has gained widespread acceptance among scholars. See among the many Y. Benkler, The Penguin and the Leviathan. The Triumph of Cooperation Over Self-Interest, New York, (2011); 'Sharing Nicely: On Shareable Goods and the Emergence of Sharing as a Modality of Economic Production', 114 Yale L.J. 272 (2004); in the perspective of knowledge economics C. Antonelli, 'Compulsory Licensing: the Foundations of an Institutional Innovation' 4 WIPO J. 157, (2013), and has eventually been taken up also by mainstream media: see the Editorial 'The new model sharing economy' Financial Times, London, 10-11 August (2013). For additional references see my paper 'Copyright Policies for Digital Libraries in the Context of the i2010 Strategy', presented at the 1st Communia Conference, Louvain-la-Neuve, Belgium (1 July 2008), available at <http://www.communia-project.eu/node/110> accessed 29 April 2014 and my earlier article 'Da Chicago al Ciberspazio' inClerico and Rizzello quoted above at note 1,83 , especially at 94 . The idea of an approaching paradigm shift is to be found in the seminal works by E. Volokh, 'Cheap Speech and What it Will Do', 104 Yale L.J. 1805 (1995) and, even earlier, by I. De Sola Pool, Technologies of Freedom, Cambridge and London, (1993).

3 By this expression I refer to the legal systems of the States which are members to the Paris and Berne Conventions or became parties to them by signing the WTO-TRIPs agreements. 
by three technological features of digital resources Sections III.A-D) which have become essential components of the process of creating works and inventing technologies: digital resources are non-rival in production as well as in consumption; they are complementary; and their combination in re-use is not predictable ex ante.

After articulating these claims, I will explore a few of the (many) corollaries which flow from them. After briefly sketching out the pillars on which the new paradigm is based and discussing the legislative agenda which is appropriate to maximize its contribution to societal welfare (section VI), I will turn to identifying the legal tools required to engage in the transactions which typically take place among the players involved in the process of generating and disseminating new creations and technologies under the emerging paradigm (sections VII-VIII). In the past, the legal tool we usually categorize as contract or agreement was the centerpiece on which transactions concerning works and technologyincorporating goods rested. I suggest that in the current digital networkdriven context the role played by contract is receding, while the role played by contract's lesser brother, for present purposes characterized as 'unilateral act', is gradually expanding. Indeed, a growing body of evidence shows how on line cooperation in creativity and innovation resorts more often to unilateral acts than to contracts, agreements or contractual arrangements; in turn, hybrid business models, where the free provision of goods and services ('gifts') is complemented by price-based market transactions, are coming center stage. These developments may call for a radical rethink both of the theory and practice of unilateral acts, and particularly so in the crucial areas which are affected by the digital nature of the resources shared or exchanged. More specifically, it would appear that the time has come to ask once again whether we should still stick to the belief, current in some jurisdictions, that unilateral acts are typical rather than a-typical (as contracts are); whether they are revocable or not; and finally (section IX) whether it makes sense at all that the rules concerning them still are municipal rather than global. 


\section{THE TRADITIONAL CASE FOR THE INCENTIVE ROLE OF EXCLUSIVITY IN THE OLD PARADIGM}

The case for conceiving exclusivity as the cornerstone of the old creativity and innovation paradigm has been very strong all along. ${ }^{4}$ There is no doubt that new works and new technology are not manna; they do not fall on us from the sky. On the contrary, as great scholars have shown over the centuries, they are public goods; which means that the market mechanism as such is not able to provide the level of creativity and innovation optimal for society. The failure of market forces to bring about the optimal level of creative works and innovative technologies is explained by twin features which characterize both creativity and innovation. The two features are well known: public goods consisting in information and knowledge are non-rival in use, meaning that the use by an individual other than the creator does not subtract anything from the creator herself; at the same time they are non-excludable in possession, meaning that once the information is 'out', that is disclosed by the creator, she is not by herself able to prevent its duplication by third parties, including imitators and 'free-loaders' who take advantage of the effort and ingenuity of innovators.

It has been magisterially been shown that market failure in the provision of public goods may be overcome by one or more of legal devices, or a combination of them: either exclusivity, in the form of a property right (Property), or Patronage, i.e. a reward given by political or private powers to creators and innovators, or, finally, by Procurement, that is by having governments contracting out (for a price) the provision of novel works and technologies.

4 For a classic treatment J. Hirshleifer, 'The Private and Social Value of Information and the Reward to Inventive Activity', 61 Am. Econ. Rev. (1971) 561 and W. M. Landes and R. Posner, 'An Economic Analysis of Copyright Law', XVIII Journal of Legal Studies 325 (1989). For a thorough rethinking see J. Lerner, 'The Patent System in a Time of Turmoil', WIPO J. (2010) 28. It should be noted that the argument developed in the text does not apply to trademarks, as these are not public goods: see W. M. Landes and R. Posner, 'Trademark Law: an Economic Perspective', (1987) XXX Journal of Law and Economics 265, 274 ('a proper trademark is not a public good; it has social value only when used to designate a single brand'); indeed the essay by Libertini, quoted above at note 1, in his comprehensive review of the role currently played by IP appropriately reserves a special position to trademarks. 
A property right is a legally enforceable power to exclude others from using a resource. ${ }^{5}$ The legal tool of exclusivity provides the crucial - and otherwise missing - incentive to creation and innovation. The power to exclude others from duplicating and imitating the novel work or technology guarantees that the creator or innovator, by preventing the free-riding or free-loading by unauthorized third parties, may appropriate the value added by her novel work or technology. ${ }^{6}$ Exclusivity thereby supplies (ex ante) the incentive and (ex post) the reward for the investment, of time, effort and money, necessary to generate them. ${ }^{7}$

5 Landes and Posner, 'Trademark Law', ibid., 266.

6 On the link between the general theory of property rights as tools to foster optimal allocation of resources and the rationale for granting exclusivity to IP see for further detail section V.A.1.

7 Of course, the benefits provided by exclusivity are not limited to the incentive-reward function referred to in the text. For an account of the other functions of intellectual property protection, and namely the dissemination, disclosure and public domain functions, see K. Arrow, Economic Welfare and the Allocation of Resources for Invention, in The Rate and Direction of Inventive Activity: Economic and Social Factors (National Bureau Committee for Economic Research), Princeton, N.J., (1962) 609 and R. Mazzoleni and R. R. Nelson, 'Economic Theories about the Benefits and Costs of Patents', XXXI Journal of Economic Issues(1998), 1031. For a treatment of the specificity of the costs and benefits of copyright protection vis-à-vis patent protection see $\mathrm{N}$. Weinstock Netanel, 'Copyright and a Democratic Civil Society', 106 Yale L. J. 283 (1996) and David, quoted above at note 1, 9.

It is also well established that exclusivity entails large costs, which have to be balanced against the benefits when the question arises whether a property rule should be established to begin with and what are the optimal ways to determine its scope and term. While the potential for output restriction and - to a certain extent - for disincentive to downstream creativity and innovation has been extensively discussed by classic economic theory and economic analysis of law literature, in recent years the attention has encompassed less obvious costs of exclusivity: see Antonelli, above at note 1, 161, emphasizing the self-reinforcing feature whereby incumbents in technology intensive sectors may use past competitive advantage in innovation to perpetuate the exclusion of potential newcomers. 


\section{WHY IN THE DIGITAL ENVIRONMENT THE INCENTIVE PROVIDED BY EXCLUSIVITY IS NOT ALWAYS REQUIRED}

Against this background, it is entirely reasonable to ask why in the digital environment the incentive provided by exclusivity should no longer prove as necessary as it was for a long time in the analogue world. Indeed, I still vividly remember an exchange of views precisely on this issue between Tony Kronman and Larry Lessig in a conference in Torino back in 1999. Professor Kronman made the case that the flurry of innovation and creativity which had been prevailing in the first decade of the internet could only explained in terms of a one-off spurt of imagination and fantasy triggered by the novel infrastructure. However, as kids get tired of new toys after a while, and leave them neglected in a corner after the first rush of enthusiasm has abated, he argued, also creativity and innovation over the net will taper off, unless the 'immutable' laws of economics set in once again and the incentive provided by exclusivity is thus set in motion also in the virtual world. I do not remember that Professor Lessig's reply was particularly convincing. ${ }^{8}$ Indeed the reply to the incentive-in-the digital environment question is not an easy one and time would be required before the outline of a possible explanation could emerge. Maybe the time has come when we may start to glean the components which go in to the reply. Let me therefore try to cobble them together.

\section{A. The Change In the Social and Technological Basis of Creation}

Let us start from the copyright side of the issue, by looking first at the question of the continuing necessity of incentives in a digital environment from the perspective of the creation of those entities which are apt

\footnotetext{
8 Actually, on that very occasion Prof. Lessig made an important point, arguing that the power of monopoly and control previously held by upstream businesses was being eroded by the architecture of the internet, which is designed to allow for freedom to innovate in the end-layers of the infrastructure; and that this newly acquired freedom accounted - and would in the future account - for the extraordinary rate of creativity and innovation witnessed on the web. However, this explanation contains only a half-truth: removing an obstacle is not the same as providing an incentive.
} 
to be protected by copyright, that is - in common IP parlance - 'works'. ${ }^{9}$ In this connection, one development has become increasingly clear: in our post-post-industrial age, the long route which used to lead the work from its creator to the public by passing through business (and sometimes different categories of businesses) is gradually being replaced by a short route, which puts in direct contact creators and the public. This development, which ultimately is bringing about the merging of producers and consumers of works (and making them 'pro-sumers'), should be briefly sketched out in its social and technological underpinnings. ${ }^{10}$

\section{The social dimension: From the long route ...}

In the analogue word, direct access to the market by creators was confined to a limited number of very special cases. ${ }^{11}$ Otherwise, it could be taken for granted that the intermediation of businesses was necessary to bring works from creators to markets. In particular, impresarios were required to organize performances; books and records needed to be printed. For this latter purpose some kind of 'factory' was required, to manufacture what in effect were fixed, stable, material or - as the expression now goes - 'hard' copies of the work. In turn these hard copies needed to be stored, transported, distributed, before reaching the shelves where the public would finally find them.

It was difficult for creators to engage in all these steps; and this is why, as a rule, they preferred to resort to businesses to set up the characteristic trilateral relationship between creator, business and the public, which is typical of primary exploitation of copyrighted works. ${ }^{12}$ The kind of business, which appeared indispensable for this purpose, had features which the last few centuries made familiar. To begin with, it had to make substantial outlays to figure out whether there was a market for the work; then again it had to invest, and take correspondingly large risks, for the setting up of the performance or the mass production of material copies

9 As we will see (below at section III.B.1) a not very different reasoning may extend to the close relations of copyright which we European scholars conceptualize as neighboring or related rights, including data base sui generis right.

10 For additional references see my 'Individual and collective management of copyright in a digital environment' in P. Torremans (ed.), Copyright Law. A Handbook of Contemporary Research, Cheltenham, (2008), 282, 285 and 308.

11 Such as the painter personally seeking out patrons to sell his paintings or the wandering gipsy carrying around his violin.

12 See in this connection W. R. Cornish, Intellectual Property: Patents, Copyright, Trade Marks and Allied Rights, London (1996) 401. 
of works and for their distribution; and this on a scale which increased in step with the extension of the markets. Publishers, Hollywood and the record labels are appropriate cases in point. Radio and TV came in to take care of so-called 'secondary' utilization of works.

In all these regards, it certainly can be said that this was a quite long route to institute a contact between the creator and the public; and that business was a very valuable, indeed indispensable, intermediary to achieve such a goal. In this context, exclusivity played a crucial role. Businesses would never have undertaken the risk of the investment required of them if they were not allowed to engage in price-based market transactions to recoup it; exclusivity - that is the legal rule prohibiting rival performances or the sale of unauthorized copies of books or records - was the indispensable tool to provide the corresponding incentive. As a rule, also 'creators' were professionals: professional playwrights, novelists, music composers and so on. Royalties and remuneration provided the wherewithal for their living; but none of these would come out of businesses pockets if exclusivity, and the price-based market transactions it enabled, were not available. ${ }^{13}$

\section{2. ... To the short route}

In the digital environment all this dramatically changes. On the production side, perfect, infinite and costless digital copies make 'factories' of physical, material copies of works redundant, at least in principle. ${ }^{14}$

On the distribution side a similar - possibly less visible, but certainly even more striking - process has been taking place for some time now. This is so because digital goods distributed through the net are light rather than heavy, and use up a (very) limited amount of storage space. But even more so because the technological endowment held by the

13 For a brilliant account of the - peculiar, but not surprising - legal invention whereby exclusivity was vested in the creators rather in businesses see W. R. Cornish, 'Authors in Law', 58(1) Modern Law Review (1995), 1.

14 It may be argued that this is true only for additional copies, the ones which can be costlessly multiplied after what we could call the initial embodiment, the prototype or 'master' has been first created; and to this it may be added that the investment required for the latter still is huge. This objection has indeed been raised a number of times [e.g. by P. Auteri, 'Diritti d'autore, nuove tecnologie e Digital Rights Management', in M. L. Montagnani and M. Borghi (eds) Proprietà digitale: diritti d'autore, nuove tecnologie e Digital Rights Management, Milano, (2006) 23; but the argument is not always less defensible. Indeed, the role of software and of digital technology in the creation and initial fixation of music is increasing all the time; accordingly the cost even of the initial fixation may in parallel be shrinking. 
public at the receiving end has in the meantime been transformed. Even in the past the end user had to make an investment of sorts in technology, by purchasing a radio or a TV set, a record player or a tape recorder. The novel feature is that since the beginning of the digital age the scale of a minimum unit of the technological endowment at the receiving end - e.g. the memory of a PC - has started to be largely in excess of the average needs of the consumer; ${ }^{15}$ and as a rule each unit is interoperable with all the others. A similar analysis can be corroborated by looking at filesharing. Whatever legal assessment we may pass of this practice, its ultimate technological ramifications cannot be in doubt: here we have enormous excess capacity residing with the public at large at the receiving end; and this excess capacity can be mobilized to create distributive networks of extraordinary scale, scope and effectiveness.

In this novel context, it would seem that the setting up of a relationship between creator and business no longer has the same compelling rationale it used to have in the past. Digital copies are (nearly) perfect; and can be duplicated at no cost at the receiving end. Therefore, in an increasingly large number of situations both the 'factory' and the physical distribution chain are no longer indispensable. It appears therefore that creators can more and more often access markets without engaging in the trilateral relationship which used to be characteristic of dealings in copyright. Indeed, these technological determinants enable creators to make works directly available to the public. It is even more remarkable that an increasingly large number of members of the public itself are in turn grabbing the opportunity offered by the technology available at the receiving end and transforming themselves into producers and distributors of works.

To cut a long story short: both the production and distribution functions migrate from business to the public and there they can rely on excess resources available at each consumption unit. These, if individually of small scale, may be multiplied by very large numbers to provide almost infinite manufacturing and distribution capacity in a way that dwarfs past industry investments and makes them to a large extent redundant. ${ }^{16}$

The stage scenario has indeed changed. Social sharing enters; business recedes. As a result, the long route from creators to the public is becoming much shorter; and this is happening more and more all the

15 As noted by Benkler, 'Sharing Nicely', above at note 2, 277.

16 On the emergence of a new generation of powerful intermediaries, see however below sections III.E, VI.C, VI.D.3 and VI.D.4. 
time. Today creators set up their own sites and make text and music directly accessible to the public therefrom. ${ }^{17}$ Currently, user generated content and social networks are growing exponentially: creators and public are finally merging into each other. To make a long story short: the British Encyclopaedia is in the past; Wikipedia is an extraordinary success; and yes, Encarta, the digital encyclopedia created by Microsoft which was based on the old, proprietary, market-based approach was a true flop.

\section{B. On Being Digital: The Technological Determinants of Exclusivity and Openness in the Dissemination of Digital Copies}

Of course, the process which has brought works from the long route to the short one also has an obvious technological dimension. Let us take a closer look at it.

\section{Infinite, costless and perfect copies}

As long as works were brought to the market along the long route, it was essential for creators and even more so for businesses to control and restrict access to works, as the monopoly granted by expansive exclusive rights enabled them both to keep out free-riders and imitators and accordingly to charge whatever price the market would bear. Thus the exclusivity granted by copyright used (and uses) the leverage given by IP protection to maximize returns by controlling and restricting the ways in which the work is from time to time exploited by means of price-based market transactions.

This long-established modus operandi is frontally challenged when the exploitation of works no longer takes place in the bricks-and-mortar world of music theatres, books, records, radio, movies and television and is based instead on digital and intangible copies rather than of entities which are tangible or located in a bricks-and-mortar context.

A few remarks may be in place here to visualize the implications of the transition from analogue to digital, from bricks-and-mortar to virtual. The first one concerns the place of intangible digital copies in IPR theory. In IPR theory, while the object of the IPR, be it a logo, an invention or novel, is an ideal entity, the - potentially infinite - copies

17 On the early beginnings of the phenomenon, when Stephen King set up a site to allow readers to download his latest short story, 'Riding the bullet', at \$2.50 per download, see J. Epstein, 'The Rattle of Pebbles' The New York Review of Books, New York, 27 (2000) 55, 57-8. However, to a large extent the diffusion of e-books entails a re-intermediation of the field. 
which might embody it, be they Coca Cola bottles, brakes or books, have a discrete, physical, material, tangible ('hard') existence, locating them in the bricks-and-mortar world. This duality of IP is described in the tradition of classical IP law by contrasting the ideal (corpus mysticum) and the real entity (corpus mechanicum). In this connection, we should keep in mind that also digital copies are corpora mechanica, in that they are material, physical copies, even though intangible ones. While we may not touch them in the same way as we touch a book or a record, nevertheless they consist of electric or magnetic currents, forming a predetermined sequence of bits, which has a separate, discrete existence from other sequences of bits. ${ }^{18}$

Second, also digital copies, intangible as they may be, can be incorporated into stable, material embodiments, be they the plastic medium of CDs or DVDs or the discrete location assigned to them in a server or in another device.

Third, and more importantly for present purposes, they differ from tangible copies in that they may be multiplied in infinite numbers of perfect copies at a cost which approximates zero. These features of digital copies were mentioned earlier; we revert to them here to underline that they mark an important discontinuity with the past: while additional Coca Cola bottles, brakes and books do require the using of a certain amount of physical resources to be manufactured, this is not the case with digital copies, which can be duplicated at no cost by whosoever happens to lay their hands on the corresponding electronic file.

Earlier we saw how these features account for the revolutionary developments which have led from the long to the short route in the trajectory which puts creators in contact with their public. Now we should turn from the analysis of production and distribution modes to the legal tools which enable them and add that the same features, viewed with the lenses of legal theory, account for the reason why digital copies have been disseminated from their creators to the public according to two radically different transaction models. This bifurcation deserves close exploration, as it highlights very different attitudes towards exclusivity.

The first mode came to the fore in the sixth decade of last century in the form of proprietary software licensing ${ }^{19}$ and has been followed by agreements providing, inter alia, for the making available in digital form of works and content (digital publishing) or of data sets (data base

18 See R. Romano, L'opera e l'esemplare nel diritto della proprietà intellettuale, Padova, (2001), 152 and note 35 at 224.

19 See I. V. Heffan, 'Copyleft: Licensing Collaborative Works in the Digital Age', 49 Stanford Law Rev. (1997) 1487. 
agreements). Also proprietary licensing is based on exclusivity, exactly as the dealings with IP-incorporating goods and physical copies, except that here exclusivity comes with a vengeance: as digital goods are prone to escape licensor's control (information is liquid or, as it was famously said, 'wants to be free'), an extra effort is made to restrict by means of contract, law and technology the chance that end users of a digital copy duplicate it and re-distribute it, thus becoming competitors of licensor. In this first variety of digital licensing ('proprietary', 'market based' and 'closed'), the goal has been to enlist all possible tools to ensure the strictest control over digital copies not authorized by the licensor and thus to assure the continued feasibility of price-based market transactions. This goal has been pursued both by contractual and technological means, that is, by having licensee contract away whatever limitations and exceptions she may enjoy and by resorting to technological measures (which may be described as DRM or TPM depending on the circumstances) to prevent unauthorized duplication and by invoking legislation banning circumvention of technological measures. ${ }^{20}$

There is also a second variety of digital licensing, however. Its story is particularly relevant in the present context, so it deserves some mention, even though it has been told and re-told many times. It starts in the early 80 s with the emergence of free open source software (FOSS) and extends to works other than software by means of copyleft and 'free' licenses such as Creative Commons (CC). ${ }^{21}$

20 On Digital Rights Management (DRM) and Technical Protection Measures (TPMs) see G. Ghidini, 'Exclusion and Access in Copyright Law: The Unbalanced Features in the Infosoc Directive' in G. Dinwoodie (ed.), Methods and Perspectives in Intellectual Property, Cheltenham, (2013), 307, 321 and S. Von Lewinski, 'Rights Management Information and Technical Protection Measures as Implemented in EC Member States', 35 IIC 844 (2004) (both in the specific perspective of EU copyright law) and, for early (and more general) accounts, T. Vinje, 'Copyright Imperiled', EIPR (1999), 192, 197; J. Cohen, 'WIPO Copyright Treaty Implementation in the U.S.: Will Fair Use Survive?', EIPR 236 (1999); L. Lessig, Code and Other Laws of Cyberspace, New York (1999) 213 and K. W. Dam, 'Self-Help in the Digital Jungle', The Journal of Legal Studies (1999), 393.

21 On open source software see Y. Benkler, 'Coase's Penguin, or, Linux and The Nature of the Firm', 112 Yale L.J. (2002) 369, 374; for a treatment of FOSS licenses in the perspective of Italian law see V. Zeno-Zencovich and P. Sammarco, 'Sistema e archetipi delle licenze open source', AIDA (2004) 234. On Creative Commons (hereinafter referred to a CC) see B. F. Fitzgerald, J. M. Coates and S. M. Lewis (eds), Open Content Licensing: Cultivating the Creative Commons, Sydney, (2007) and N. Elkin-Koren, 'What Contracts Cannot Do: The 
In this second variety of digital licensing, the approach towards exclusivity has been exactly opposite to the strategy pursued by proprietary, market-based licensing. To begin with, here the licensor typically gives up one or more of the exclusive rights she is legally entitled to ('some rights reserved', as opposed to 'all rights reserved'). Here IP exclusivity is used as a tool to open rather than to restrict. Licensees are authorized to use the licensed subject matter, provided that they abide by the rules contained in the license; in turn, these rules are intended to keep re-use free. The terms of the license intend to make the digital resource 'open'; and, according to a widely followed definition, 'a piece of data or content is open if anyone is free to use, re-use and redistribute it'..$^{22}$

This approach in favor of openness differentiates the second variety of digital licensing both from the traditional exploitation modes of works in the brick-and-mortar context and from the first, proprietary, variety of digital licensing, which have in common the feature of building on an unmitigated reliance on exclusivity to enable price-based market transactions.

What accounts for this quite strikingly novel approach adopted by the second variety of digital licensing, as shown by the specific features of FOSS, CC and the other alternative licenses? To sketch out a tentative reply we will need to go beyond the - by now well-established - point that digital copies are perfect, costless and infinite and have another look at the technological and social determinants of the phenomenon.

Limits of Private Ordering in Facilitating a Creative Commons', 74 Fordham L. Rev. (2005), 375. The connection between FOSS licensing and other forms of open licensing is highlighted by A. Metzger, 'Transnational Law for Transnational Communities: The Emergence of a Lex Mercatoria (or Lex Informatica) for International Creative Communities' Jipitec (2012), 36.

22 '[S]ubject only', the definition goes on to state, 'at most, to the requirement to attribute and or share-alike': see http://opendefinition.org/> accessed 10 May 2014. On the 'viral' feature of share-alike licenses and the so called 'copyleft clause', which requires the licensee to make all his additions available under the same open access conditions to all subsequent users, see also for further references my 'Public Sector Information as Open Data. Access, Re-Use and the Third Innovation Paradigm' in M. Ricolfi and C. Sappa (eds), Extracting Value from Public Sector Information: Legal Framework and Regional Policies, Naples, (2013) 3, 26. Reference to the 'viral' feature originates from software licenses, whereby the original condition imposed by the first licensor to the first licensees is propagated by the latter downstream, exactly as a virus would do, to cover each and all pieces of software building on the basis of the initial chunks of programming. 


\section{Non-rivalry in production and complementarity in re-use of digital resources; ex-ante unpredictability of their combination}

The second variety of digital licensing builds on two additional specific technological features of digital copies, that is their non-rivalry both in consumption and production on the one side and on their complementarity in re-use on the other. Not only are digital copies perfect, costless and infinite, as we just saw in accounting for the transition from the long to the short route; there is much more to their being digital. These additional features may be captured by remarking the simple fact that one person's use of a digital copy does not subtract anything from the consumption of the next user; they are, in other words, non-rival in consumption. Moreover, when we take into account that digital copies, being amenable to being multiplied into infinite, costless, and perfect copies, may be also used as inputs for the production of any number of downstream goods and services, we come across an extraordinary feature which is unheard of in the bricks-and-mortar which was our only point of reference until two decades ago: digital copies are non-rival also in production. ${ }^{23}$ While in the bricks-and-mortar world the metal used for building this specific Coca Cola can is taken away from its possible alternative use in manufacturing that brake, the same Google Map may be used both for building on it an application dedicated to bikers wishing to avoid showers and to specialist oil rig repair engineers; ${ }^{24}$ an application indicating the location of hamburger joints and an emergencyapplication used to help out people trapped in a devastating fire. ${ }^{25}$ In other words, one of the most remarkable features of digital assets is that they are amenable to joint production, that is if technical protection measures and law do not stand in the way.

23 The link between the possibility of creating infinite, costless and perfect copies on the one side and non-rivalry in production and complementarity in re-use is illustrated in its general terms in connection with digital assets by $\mathrm{J}$. Hofmokl, 'The Internet Commons: towards an Eclectic Theoretical Framework', 4 International Journal of the Commons (2010), 226, 243. For a similar analysis from the perspective of knowledge economics, albeit with slightly diverging terminology (referring to the features of knowledge rather than digital resources and characterizing them as non-exhaustibility and cumulability) see Antonelli, above at note 2,160 .

24 For an illustration see Deloitte, Tech4i2, and Others, European Commission, Information Society and Media Directorate-General, of Public Information Sector Study' Summary Report, 16, <http/::www.epsiplatform.eu:sites:default: files:summary.pdf> accessed 25 April 2014.

25 As happened in Queensland during the horribly hot 2011 summer. 
Additionally, digital assets show a strong complementary character in re-use. They may be combined, mixed or 'matched' to create a new product or service; and in turn these first-generation products or services may be further used as intermediate inputs for additional derivative products and services downstream.

As a matter of fact, non-rivalry and complementarity are features which apply to all digital assets. However, this common feature is dealt with in very different ways by the two varieties of digital licensing we referred to earlier. While the purpose of the first kind of digital licensing is to defuse, by legal and technological means, the potential implicit in non-rivalry in production and complementarity in re-use of digital assets, by restricting and disabling non-authorized re-use, the second kind of digital licensing (in its different shades of being 'non-proprietary', 'non-market' and 'open') strives to harness the same potential for its own specific purposes: non-rivalry in production and complementarity of digital assets are the basis on which the strategy of fostering and encouraging dissemination, particularly over digital networks, is built.

It should finally be noted that the way in which digital resources may be combined to create novel goods or services is ex ante unpredictable. Even in this connection, the second variety of digital licensing takes an approach which is exactly opposite to the one adopted by all forms of price-based market transactions. Indeed market transactions concerning IP-incorporating goods aim to avoid ex ante unpredictability, by striving to reach the completeness of contract terms which may be required to make sure that profit maximization is obtained.

The reason why the second variety of digital licensing builds on ex ante unpredictability is not difficult to understand: the mixing and re-mixing of digital assets, the matching of digital data sets, unanticipated combinations are all encouraged across the board, as they lead to a more widespread re-use of the digital resource. Here the digital challenge is seen not as a threat but as an opportunity. To understand why this is so, we should turn to the social basis of on line creativity.

\section{Where Society and Technology Meet: the Grammar Of Interests In the Second Variety of Digital Licensing}

What are then the goals of creators operating along the short route? For sure we know that they are not so clear cut as the ones which prevailed (and prevail) along the long route and which can be encapsulated by reference to the formula of profit maximization via price-based market transactions. 
However, the evidence available may give us some clue. The great majority of the creators operating along the short route, be it 9 out of 10 or 95 out of 100, do not make a living out of 'sales' of 'copies' of their works; they earn their livelihood in another activity or line of business and devote a portion - often a very large portion - of their spare time to 'creating'. Their contributions (actually: our contributions) may be very different: photos, music, audiovisual materials, blog posts, other text, all made available digitally over the net. What we are witnessing here is not the emergence of a new group or class or society section of creators; we are witnessing a re-modulation of the ways of life of over a billion people from every walk of life who devote part of their time, energy, and resourcefulness in making contributions available over the net.

From the economist's perspective, these contributions may fall into two categories: either they are gifts or, in the alternative, components of a wider set of transactions ('hybrid' transactions, or just 'hybrids') which have an element of gift and an additional, for profit element, more or less loosely linked to it.

Let us look at the two categories of contributions separately.

The gift component is best exemplified by looking at Wikipedia. Contributions to Wikipedia items are totally free, that is, the contributor does not receive any kind of remuneration, either monetary or otherwise. Also the paternity attribution, or 'credit', received as a rule is so minor as not to be relevant to the transaction. There is an element of reciprocity, however. ${ }^{26}$ Contributors are willing to contribute their small grains of information or knowledge, on the understanding that others will do the same with the different grains of information and knowledge these others may possess. Fragments are contributed to the larger canvas on the assumption that the canvas will be eventually completed by other fragments; and that the canvas itself will be complemented by other canvases.

Hybrid transactions have been studied even more closely. ${ }^{27}$ Indeed, their blueprint was provided quite a long time ago by that forerunner of the second variety of licensing which is FOSS; and its scope is constantly being enriched and enlarged by the ingenuity of internet- and digitally savvy individuals and communities. Usually, also these digital contributions, from free music over the net to Flickr images and photographs, are given away for free, i.e. they do not generate extra income for the person

26 Y. Benkler, 'The Penguin and the Leviathan' quoted above at note 2, 29.

27 In this connection see L. Lessig, Remix. Making Art and Commerce Thrive in the Hybrid Economy, (2008) 177; Antonelli, above at note 2, 162. 
who is contributing them. However, they tend to have positive spill-over effect on the main line of business of their contributors, as they facilitate the 'discovery' of the same contributors by the relevant constituency and may give them recognition, professional credit or a combination of the two and to pave the way for price-based market transactions concerning professional services which are complementary to the freely disseminated digital goods. Even when the creators operating along the short route are professionally engaged in the creation of works, which normally is not the case, their business model usually is based on income flows different from the sale of digital copies as such. To exemplify and to give a flavor of what is going on, let me mention that there is a shift whereby even singers and songwriters increasingly rely on performances, tours, endorsements, merchandizing and their like ${ }^{28}$ rather than sales of albums and tracks.

This is the business model which the Grateful Dead pioneered and which is currently expanding to an increasing number of initiatives. So that the eminent economist Paul Krugman a few years ago argued that the demise of reliance on income based on 'hard' copies was being generalized and, making his case, quipped that in the long run we will all be the Grateful Dead. ${ }^{29}$ What is important for creators engaged along the short route is, it would appear, that their work can be disseminated as widely as possible, on the condition that the work is correctly attributed to them.

While at first blush it might appear that both approaches are revolutionary, it turns out that even from a strictly economic viewpoint they make a lot of good sense, on a number of grounds. Indeed, it has been convincingly shown that economic decisions are made and resources are allocated not only on the basis of market-based exchanges and firm-based hierarchies, but also on the basis of sharing or peer production. ${ }^{30}$ The case has also been persuasively made that this latter mode of production is likely to gain traction in network-driven digital environments, where it

28 Including revenue from product placement embedded in virally disseminated video clips (as magisterially shown by Lady Gaga).

29 P. Krugman, 'Bits, Bands and Books', New York, 6 June 2008). This trend seems confirmed by the current behavior of 'traditional', 'legacy', businesses, which are indeed seeking to obtain a share of these novel income streams.

30 See Y. Benkler, 'Sharing Nicely', above at note 2, 277 and 'Coase's Penguin', above at note 21, 369, where there are additional references. 
takes the form of distributed cooperation. ${ }^{31}$ Indeed, at the time when the cost of technological resources has dramatically decreased, it turns out that distributed modes of production may at times have distinctive competitive advantages over markets and hierarchies in dealing with information; and that the net enables forms of cooperation based on modularity of tasks, communication and community building which in several instances have consistently outperformed even the very best businesses. ${ }^{32}$

It should also be noted that the second variety of digital licensing is apt to give an important contribution in terms of social and public value, besides the market value they may generate. This is the obvious aftermath of an approach whereby digital resources may be incorporated for free and without strings attached in the building of downstream products and services which often entail the creation and dissemination

31 See Y. Benkler, The Wealth of Networks. How Social Production Transforms Markets and Freedom, Yale (2006) also available at <http://www. benkler.org/wonchapters.html> accessed 25 April 2014.

32 See Y. Benkler, The Penguin and the Leviathan quoted above at note 2, 169; Antonelli, above at note 2, 160, remarking that knowledge spill-overs may account for a substantial portion of economic growth, i.e. total factors productivity, which cannot be attributed to traditional productive inputs (land, labor and capital). It has been argued (by M. Libertini, quoted above at note 1) that 'hybrid' models, based on income derived from advertising and from ancillary services, entail the danger that the supply of creativity is driven by demand for advertising and of other ancillary services. I am not sure that the two advertising and ancillary services - may be lumped together, even though sometimes it may be analytically difficult to disentangle the one from the another (as shown by the example of product placements embedded in video clips referred to above in note 28); moreover, I would support the idea that many of the ancillary services which are supplied under the hybrid model have significant positive economic and non-economic value (in the latter connection see the text accompanying the next footnote). A point similar to the one last made is suggested by Antonelli, 162, which regrets that what here is described as the 'hybrid' model has a large measure of specificity, so that, where it is not at work, the system of dissemination of cumulative knowledge may come to a screeching halt. Indeed, the second part of this scholar's work, 163, may be understood as a valiant effort to overcome the problem thus identified by laying the theoretical foundations for a system of generalized compulsory licensing in the field of technological innovation where 'hybrid' models do not seem to be operating.

However, Prof. Libertini's point draws our attention to an important issue: 'hybrid' models are not self-contained systems; rather they are at the cross-roads with traditional, 'legacy', business models and the brave new world of platforms (on which section III.E); so that their role can be assessed only on the basis of their interactions with these other two sectors.

Column\$ Design XML Ltd / Job: Drahos-Kritika_Essays_on_Intellectual_Property-x / Division: 06-ch6_tracked /Pg. Position: 18 / Date: 
of public goods. ${ }^{33}$ Therefore their value may be measured not only in terms of dollar benefits to the parties to the transaction, but also of positive externalities, that is value to third parties which are not privy to the license. In classic IP licensing, as well as in digital licensing of the first variety, this feature is at best incidental.

The quantitative and qualitative importance of sharing may be visualized considering a simple table concerning economic choices. This matrix may be designed as follows: ${ }^{34}$

Table 6.1 Economic choices matrix

\begin{tabular}{lll}
\hline CHOICES & Market & Non market \\
decentralized & price & $\mathrm{X}$ \\
centralized & firm & regulation \\
\hline
\end{tabular}

It has been noted ${ }^{35}$ that usually in modern economic analysis we concentrate on the three boxes which have labels (price, firm, ${ }^{36}$ and

33 Thus the Italian service 'Voglio il ruolo' ('I want tenure') gives subscribers access to openings for high school teaching positions, in view of enabling candidates to select the schools to which apply for a permanent position as a teacher (see A. Longo, 'Fare affari con gli open data' Il Sole 24 Ore, Milan, (2012), 47. The data set and the services built around it and by 'matches' with other data sets would appear to reduce the opaqueness of school labor markets and to enable more targeted teachers' mobility in the school sector. It may therefore be assumed that the output created by matching the various data sets is liable to create welfare benefits in the form of externalities benefiting also third parties, including pupils. These benefits are likely to go well beyond the willingness to pay by interested teachers as measured by the sum of subscription prices and are sure to exceed whatever willingness to pay the third-party beneficiaries (schoolchildren and parents) may hypothetically have. The relevance of non-market value, including public and social value, for assessing contribution to welfare is often considered both by generalist and open data and Public Sector Information (PSI) specific literature: see respectively B. M. Frischmann, 'An Economic Theory of Infrastructure and Commons Management' Minn. L.R. (2005), 917, 982 and D. Newbery, L. Bently and R. Pollock, Models of Public Sector Information provision via Trading Funds (Study commissioned jointly by the Department for Business, Enterprise and Regulatory Reform (BERR) and HM Treasury), (2007), 25 and 45.

34 This matrix is taken from Benkler, 'Sharing Nicely', above at note 2, 276.

35 By Benkler, 'Sharing Nicely', above at note 2, 276.

36 For all purposes, the term 'firm' used henceforth should be considered an equivalent to the expression 'business'; except that in this part we prefer to resort to the former, rather than to the latter which we employed so far, because here 
regulation). As a rule, it does not occur to us that choices may also take place in accordance with the way indicated in the box indicated with the letter $\mathrm{X}$, that is in a way which is at the same time decentralized and non-market.

There is one interesting thing in this table.

The production and distribution of works in accordance with the so-called short route would appear to be taking place in ways which are at the same time decentralized and non-market and thus belong to the box designated as $\mathrm{X}$. Decentralized and non-market choices rely on mechanisms based on reciprocity and cooperation, rather than on pricebased market exchanges. This is why that short route, with which we have been dealing so many times by now, is taking off. It is neither a quirk nor a fad; it is here to stay.

\section{Back To the Law: The Role of Exclusivity In The Second Variety of Digital Licensing}

Against this background, we may revert to our initial question, whether the incentive provided by exclusivity is really necessary in the digital environment. We are now in a position to see why the reply to this question is in the negative. The incentive provided by exclusivity may indeed be required to foster innovation and creativity and to enable its exploitation by means of price-based market transactions, as was the case when the contact between creators and their public was instituted by means of the traditional 'long route' and still is the case in the 'legacy' sectors (music labels, print-publishing, movies) where the long route still prevails. ${ }^{37}$ However, it has been convincingly shown that when innovation and creativity are based on digital network-driven cooperation among a large number of contributors, and participants may be contributing 'small grains' of their time and attention, as typically happens in peer production and sharing, then the question of incentives itself become trivial. $^{38}$ The motivation for creation here does not come in the form of a

we are discussing contributions which use the former expression and this same expression is more appropriate in the context of formal economic analysis.

37 See above section III.A and below section VI.A and VI.D.

38 Benkler, 'Coase's Penguin', above at note 21, 376. It seems to me that, when we deal with our hobbies and pet initiatives, at the intuitive level we all have knowledge that this peculiar mechanism is at work (e.g. I am certainly willing to contribute to Wikipedia all my knowledge on an exquisite football professional playing in the Juventus team in the late 60s of last century, as I expect that others will contribute on other similar players on whom I have less 
financial reward, but rather in the non-monetary rewards offered by the reciprocity of the contribution given with the ones received and - more importantly - expected. On the other hand, financial reward may loom large in the background of other online transactions; but even then it is usually derived from 'hybrid' business models relying on income deriving from non-duplicable services supplied as a by-product of the free digital copies of one's own creations, rather than on price-based market transactions over digital copies.

This means, reverting to our original question, that in the networkdriven digital environment exclusivity does not play a role as an incentive. Exclusivity, however, plays here a different role: in this context it is used as a tool to open rather than to restrict. Digital files contributed over the net are made available on condition that the license terms they carry with them are respected. ${ }^{39}$ Open source software cannot be distributed without source code; the further distribution of a CCBY-licensed song cannot be restricted by licensees; Wikipedia material can be incorporated in downstream creations, only if these carry with them the same 'viral' share-alike clause. IP protection - and specifically copyright protection - and the exclusivity it carries with it are the legal basis for the enforceability of the license: had the contributor no IP protection, disregard of the terms and conditions of the license would not have adverse effects on non-complying third parties. Conversely, exclusivity entails that the non-complying third party is an infringer. ${ }^{40}$

As noted earlier, in copyleft licenses, licensees are authorized to use the licensed subject matter, provided that they abide by the rules contained in the license; in turn, these rules are intended to keep downstream re-use free. Exclusivity is here harnessed to maximize the potential implied in non-rivalry and complementarity of digital goods and their dissemination over the networks.

information; I will make my trade mark Treatise available under a CC attribution license, expecting to have many comments, suggestions, and additions, on the parallel Wiki, just because I intend to promise to give credit for suggestions taken up); however, and interestingly enough, we do not appear to be prepared to draw from this approach the appropriate conclusions.

39 As noted by many scholars: see G. Ghidini, above at note. 20, 307, note 1. On the technological mechanisms (based on metadata) which ensure the applicability of license terms and conditions over digital networks see for details below section VII.B.

40 See Landgericht München 19 May 2004 (decree), H. Welte $v$ S. Deutschland (2004) CRi 156. For a discussion of the issue and other quotations see Metzger,above at note 21, 365. 


\section{E. A Note of Caution: The Emergence of Platforms}

In the previous pages, I (over-neatly) subdivided the world of creativity in two halves: the long route where the delivery of works from creators to their public was (and is) the responsibility of intermediaries, the businesses; and the short route, which enables creators direct access to their public and even creates a large degree of overlap between producers and consumers of works. A few words of caution are in place here. We should be aware all the time of the fact that the stylized version I proposed, while probably useful and appropriate to deal with the question whether the incentive provided by exclusivity still is indispensible, is oversimplified in a number of ways. ${ }^{41}$

To begin with, while it is certainly true that the internet has enabled a vast amount of 'disintermediation', by displacing, in whole or in part several of the businesses operating along the long route, the same internet has enabled developments working in the opposite direction. Indeed, in the last decade we have been witnessing to the emergence and to the rapid growth of new and powerful intermediaries, usually taking the shape of platforms. ${ }^{42}$ Reference is made here to Google, Amazon, Facebook, Apple, Yahoo!, Netflix and their likes. These new businesses, unsurprisingly American rather than European, would appear not to be a mere extension of the 'legacy' media businesses prevailing in the analogue world, even though some form of interlocking seems to be taking place. ${ }^{43}$ Indeed, here we are talking of businesses which could be

41 I am grateful to Gustavo Ghidini for spelling out to me this shortcoming of a previous version of this paper and for prompting me to integrate into it the missing components. sections III.E, VI.C, VI.D.3 and VI.D.4. originate from his suggestion.

42 See A. Taylor, The People's Platform. Taking Back Power in the Digital Age (2014). It is arguable that cloud computing (on which see D. Lametti, 'The Cloud. Boundless Digital Potential or Enclosure 3.0?', 17 Virginia Journal of Law and Technology, 190, (2001) calls in question the direction of the process of decentralization of technology from the hands of businesses into the hands of the public which I referred to in section III.A.2: indeed, software-as-a-service, infrastructure-as-a-service and platform-as-a-service slim down the amount of technology which both businesses and the public require in order to generate and access content; and possibly contribute to the emergence of a new generation of powerful holders of technological resources, which happen to be the same 'new intermediaries' I refer to in the text.

43 See Taylor, quoted above at note 42, 33 on cross-shareholdings and alliances between legacy businesses and new platforms; Spotify's links to labels is a good example. 
appropriately described as 'digital natives': their operations, settings, workings and strategy are all functions of digital technology.

The digital roots of platforms explain most of the features they exhibit in the supply and, even more, packaging and distribution of digital creations: to name a few, crucial ones, zero marginal costs, ${ }^{44}$ economies of scale (and of scalability) and of scope and especially positive network externalities make them candidates to take over the control over a growing portion of the supply of creations in digital format.

The potential for abuse of a dominant position held in one sector across downstream markets would appear to be huge.

We may be particularly aware of the fact that Google may favor its affiliates in downstream markets, from flight booking to media platforms, such as You Tube; but the potential for abuse in vertically integrated markets is a common occurrence wherever a common layer of digital infrastructure enables the seamless integration of disparate businesses; ${ }^{45}$ and would appear to be exponentially magnified where the key to commercial success in the downstream - or contiguous - market may depend more on the availability of vast data enabling prediction of consumers' behavior than on the intrinsic features of the good or service supplied. ${ }^{46}$

We do not know how this vast market power will be used. In the present context, we are in a position to say that platforms are candidates to take on not only the 'legacy' businesses operating along the long route (as shown by the competition against traditional labels and publishers brought by i-tunes and Amazon's e-books $)^{47}$ but also the new players

44 A feature, it should be noted, which was announced to be prevailing in digital markets over a decade ago: see Note, 'Antitrust and the Information Age: Sec. 2 Monopolization Analyses in the New Economy', 114 Harv. L. Rev. (2001), $1622,1628$.

45 The very phenomenon of vertical integration would appear to take a different meaning, when we move from bricks-and-mortar to digital business organizations. Coal, electricity, steel and cars would appear to be components of a single vertically integrated chain in the old word of the second industrial revolution, while e.g. baking and detergents would not. However, when goods take on a digital form (music, text, audiovisual, software, data sets) or even when hard, tangible goods are amenable to be supplied along a digital chain, the notion itself of vertical integration would appear liable to be greatly expanded.

46 For a similar point see Taylor, quoted above at note 42, 15.

47 On the latter see G. Packer, 'Cheap Words. Amazon is good for customers. But is it good for books?' The New Yorker 17 February 2014 $<$ http://www.newyorker.com/reporting/2014/02/17/140217fa_fact_packer?current Page=all $>$ accessed 24 April 2014. 
which in the meantime emerged along the short route. Therefore, the relevance of these 'new intermediaries' or 'platforms' deserves a closer scrutiny in the context of the current analysis of the third paradigm of creativity and innovation. ${ }^{48}$ For the moment, it will be sufficient to remark that the emergence of platforms interacts in several ways with the modus operandi of creators operating along the short route, as it impacts on the very sustainability of several forms of sharing.

For the time being, many businesses operating on the short route build on the digital resources made available by platforms which, as earlier noted, are non-rival in production; a good case in point would be the so called location based services (LBS) which build on Google maps. Maybe we had better start visualizing what would happen at the moment in which Google may decide that after all it holds valuable intellectual property rights on those maps and that it prefers to withdraw the (unilateral) authorization is has granted to complementary goods and services building on them (see in this connection section VII.D).

Also, we should consider that, as has been noted, hybrid transactions are valuable to unknown creators, if they provide creators who contribute their works for free a 'discovery value', that is if they help to bring about what I earlier referred to as recognition or professional credit of the contributor; but then being discovered is of little or no monetary value, if parallel, for-price transactions are dominated by few powerful intermediaries. ${ }^{49}$ Advertising money may well provide the wherewithal for cooperative enterprises; but it may easily dry-out once the advertising market is cornered by a limited number of giant players.

Dominance of businesses over creators has been a constant feature in the old 'cultural industry', prompting continental European - more than Anglo-Saxon - legislators to come up with rules intended to protect the artist as a weak party. The first metrics concerning platforms and new intermediaries indicate that this dominance starkly increases when these new players are involved. The power imbalance is apparent when we consider the relationship between new intermediaries and legacy players: what Hachette is experiencing these days at the hands of Amazon, that is

48 As discussed below sections VI.C, VI.D.3. and VI.D.4.

49 As the Radiohead songwriter David Byrne puts it [David Byrne, 'The internet will suck all creative content out of the world' The Guardian (11 October 2013)], an artist may well be discovered by making her music available for free over the net; but this will not help her if the only means to disseminate her music, other than by live concerts, is Spotify dominated-streaming and it (allegedly meagre) income. On the other hand, he notes, writers do not even have the opportunity to make money in live performances. 
being frankly cut off from its customers for not accepting the discounts and the fees required by its digital distributor, is something which goes well beyond the most blatant hardball tactics of brick-and-mortar distributors. It is unsurprising that the same dominance is extended, and possibly expanded, in the relationship between new intermediaries and creators. When platforms still deal with legacy businesses - e.g. music stores dealing with music publishers and labels - creators appear at the end of the line and get the smallest slice of the pie; 50 when platforms directly deal with creators operating along the short route, the latter's share would appear to get thinner and thinner all the time. ${ }^{51}$

\section{IS THE INCENTIVE PROVIDED BY EXCLUSIVITY STILL REQUIRED FOR TECHNOLOGICAL INNOVATION?}

In the previous paragraphs we dealt with the question of the continued necessity of the incentive provided by exclusivity in connection with creativity. Our conclusion was (partially) in the negative. What we had in mind were works, music, text, photographs, audiovisual works and the like; a similar reasoning would seem to apply also to entities which in our current IPR system are protected by copyright-like entitlements, such as performers' rights and data-base sui generis right.

How about technological innovation? Intuitively, the erosion of the role of exclusivity as an incentive should not be at work here; or, at least, not to the same extent as in copyright-protected creativity. Let me try to spell out this intuition. The reason why the incentive provided by exclusivity is, as a rule, no longer necessary in connection with copyrightable (or quasi-copyrightable) creations is, according to the previous analysis, that these may be the result either of the contribution of 'small grains' of individual creativity which go to form larger units by means of digitalnetwork driven cooperation or of the free provision of creations which make up a component of 'hybrid' business models.

Now, the case can be made that the field of technological innovation still remains (and will in the foreseeable future remain) firmly rooted in the bricks-and-mortar, non-digital word. Cars, wind turbines, airplanes, ice-creams and detergents are still manufactured by using physical

50 For metrics see Taylor, above at note 42, 15.

51 On the notions of 'digital feudalism' and of sharecropping - and on alternative, more optimistic ways to characterize the relationship between new intermediaries and businesses - see Taylor, above at note 42, 16. 
resources, even though a digital component is likely to be present either in the product, or process of manufacture or both, so that technological innovation tends to lead to goods which are commercialized in pricebased market transactions.52 Therefore we may safely assume that technological innovation is bound to remain to a large extent the preserve of formally organized businesses and of research centers, rather than of individuals and communities.

This does not mean that on line cooperation in research is by definition impossible; to the contrary, we seem to be witnessing the flourishing of a large number of initiatives which in fact would appear to harness the economies of scope and the scalability of network-driven cooperation to engage in large-scale endeavors which would otherwise be outside the reach even of powerful, public and private, research organizations..$^{53}$

However, digital-network driven cooperation in technological research would at the moment appear to be an exception rather than the rule, reserved for specific areas where the dimension of the problem in search of a solution by far exceeds the size of conventional players; and, more importantly, even where it takes hold, it still relies quite firmly on the incentive provided by exclusivity. ${ }^{54}$ And logically so: at the end of the

52 The 'internet of things' may in the future add an important (but separate) dimension, in terms of control by platforms (imagine independent applications interoperable only with Apple connected-home software). But this does not affect the analysis in the text.

53 For examples of this trend see the proposed 'contractually reconstructed commons' model approach originally advocated by J. H. Reichman and P. F. Uhlir, 'A Contractually Reconstructed Research Commons for Scientific Data in a Highly Protectionist Intellectual Property Environment', 66 Law \& Contemp. Probs. (2003), 315, later refined and adapted to specific contexts by A. K. Rai, J. H. Reichman, P. F. Uhlir and C. Crossman, 'Pathways Across the Valley of Death: Novel Intellectual Property Strategies for Accelerated Drug Discovery', Yale Journal of Health Policy, Law, and Ethics (2008), 1 (in connection with drug discovery). On the 'open source biotechnology' proposals see J. Hope, Biobazaar. The Open Source Revolution and Biotechnology, Harvard, 2008.

54 Even the 'contractually reconstructed commons' paradigm proposed by Reichman and Uhlir, ibid. and by Rai, Reichman, Uhlir-Colette Crossman, ibid., recognizes the benefits which can accrue if innovators are ultimately granted property rights over their research contributions and assets, while advocating contractual arrangements which may ex ante take care of the risk that players in the research community may engage in strategic behavior of the kind described by anti-commons theory (on which see belowV.A.1.). A variety of mechanisms is suggested, depending on the specific technological sector to which the arrangements are to apply, which may from case to case be drugs discovery or microbial research. There are recurring features in the design, though, among which I 
day, while private individuals may be prone to adopt, in a context which favors reciprocity and which concerns 'small grains', fragments of creativity, the logic of gift, usually this is not a feasible option for for-profit entities which have sunk and current costs to cover. ${ }^{55}$

Even so, there are signs that would appear to show that in the technological field, the incentive function of exclusivity has been, if not eroded, rounded off at the edges. I submit that this development may be detected in a number of areas, two of which deserve a special mention: a shift towards liability rules and increased resort to private ordering.

Let us look at each of these two developments.

\section{A. More Extensive Resort To a Method Of Protection of Technological IP Based On Liability (Rather Than Property) Rules}

In principle, the method of protection available for IPRs is based on a property rule, rather than a liability rule. ${ }^{56}$ In case of violation, the owner of the IP rights is entitled to have the infringement stopped (by way of injunctive relief), rather than being just compensated for the resulting loss. This is not an absolute rule, though; and the number of occasions on which liability rules are favored over full property rules is increasing. ${ }^{57}$

should mention the adoption by the different players of standard contractual forms, which contemplate non-exclusive use and access to information resources and research inputs that either are covered by some form of exclusive rights or are de facto in the exclusive possession of one of the parties; extensive confidentiality agreements limiting access by third parties to the resource; a dichotomy between non-commercial, pure research uses, on the one hand, for all purposes free and commercial uses, on the other hand, subject to a contractual liability rule whereby the party first bringing to the market a commercially valuable end-product is enabled to do so subject to a duty of compensation, in accordance with a predetermined scale of royalties, of the providers of the different inputs which may go into the end product.

55 Resort to hybrid business models is another matter; and would deserve a much more nuanced treatment. For a discussion of IBM's strategy in this respect see R. P. Merges, 'A New Dynamism in the Public Domain', 71 Chi. L. Rev. (2004), 183.

56 In the past, I argued that TRIPs mandates a property rule protection for IP: see 'Is There an Antitrust Antidote Against IP Overprotection within TRIPs?, 10 Marquette Int. Prop. L. Rev., (2006), 305, 349. I am no longer so sure now: for a (convincing) argument leading to the opposite conclusion see C. Geiger, 'Promoting Creativity through Copyright Limitations: Reflections on the Concept of Exclusivity in Copyright Law', 12 Vanderbilt J. of Ent. and Tech. Law (2011), $515,534$.

57 For a similar point see Antonelli, above at note 2, 163. 
Compulsory licensing regimes, which transform the property rule-based claim of IP into a claim for compensation, is provided for, albeit under exceptional circumstances, by Article 31 TRIPs. In some legal systems, compulsory licensing may be the remedy to antitrust violations or the result of the application of the patent misuse doctrine. ${ }^{58}$ While these inroads into the property-rule based method of protection may appear occasional and ad hoc, one gets the feeling that a much more generalized reorientation is taking place in this regard, when the courts - actually: a court as authoritative as the US Supreme Court in eBay Inc. $v$ MercExchange, $L L C-, 59$ teach us that injunctive relief for IP violation should not be, and is not, mandatory. In this perspective, the choice between protection under property or liability rules is to be made case by case.

\section{B. More Extensive Resort To Private Ordering}

Property rules-based technological IP rights may be converted into liability rules not only by dint of legislative or judicial fiat but also by means of private contractual arrangements. The attention over the phenomenon of 'contracting into liability', that is arrangements which transform property rights into contractual claims to a take part in pooled knowledge, technology or creativity or to share income streams derived by the same, is comparatively recent, even though the phenomenon as such has a quite long history behind it. ${ }^{60}$ It appears that resort to pooling arrangements of this kind is becoming particularly recurring in specific areas of technological innovation, such as climate change (e.g.:

58 See Libertini, quoted above at note 1; A. Stratakis, 'Comparative Analysis of the US and EU Approach and Enforcement of the Essential Facilities Doctrine', 27 ECLR (2006), 434; H. Hovenkamp, M. D. Janis and M. A. Lemley, 'Unilateral Refusal to License in the US' in François Lévêque and Howard Shelanski (eds), Antitrust, Patents and Copyright. EU and US Perspectives, Cheltenham, (2005), 12. This is not a novel development: recently F. M. Scherer, 'A Half Century Research on Patent Economics', WIPO J. (2010), 20, reminded us that his beginnings as a patent scholar date back to the post-World War II years in which he set about investigating $R \& D$ rates in the (about 100) firms which had been subjected to compulsory licensing as a result of antitrust investigations in the previous decades.

59547 US 388 (2006).

60 See R. P. Merges, 'Contracting Into Liability Rules: Intellectual Property Rights and Collective Rights Organizations', 84 Cal. L. Rev. (1996), 1293. Of course, FOSS and CC are quite conspicuous examples of private ordering, coming from the area of creativity rather than of technological innovation. 
Eco-patent-Commons; GreenXchange) ${ }^{61}$ and genetic engineering. ${ }^{62}$ Another significant example is provided by the voluntary pooling of IP assets in the form taken by ventures such as the MIT Media Lab, where a financial contribution gives the contributor free - if not unregulated access to the innovation originated anywhere in the common infrastructure.

What is the explanation of these developments? If the incentive theory were totally accurate, then any arrangement other than full property rights, that is unmitigated and full-fledged exclusivity allowing the IP-holder to charge all the price the market can bear by means of market transactions over the IP-incorporating products or services, should appear suboptimal, inefficient and thus unaccounted for. There must be, however, a reason which explains why on a growing number of occasions legislatures or courts decide that holders of protection over IP assets should confine themselves to a compensation rather than full injunctive relief; and even IP-holders decide that it is best for them to get together and 'contract into liability'.

One possible explanation resides in the evolution of the relationship between research and development. It was noted quite a long time ago that the length of the originally extended trajectory which leads from research results, i.e. from the creation of an innovative technology to its application on the market, has collapsed, particularly in areas as life sciences and digital technology. ${ }^{63}$ In the past, it was common to say that the two components of $R \& D$ had different weights: one unit of $R$ expenditure might entail up to 100 of $\mathrm{D}$ expenditure. ${ }^{64}$ This is probably still true in selected areas. Pharma would be a good example of this kind of dynamics. ${ }^{65}$ It is submitted however that such a multiplier is nowadays the exception rather than the rule. When the invention essentially consists of disembodied knowledge - be it a DNA sequence or an algorithm rather than tangible material embodiments, there is no need to set up

61 See M. Rimmer, Intellectual Property and Climate Change, Cheltenham, (2011), 312.

62 See G. Overwalle (ed.), Gene Patents and Collaborative Licensing Models: Patent Pools, Clearinghouses, Open Source Models and Liability Regimes, Cambridge, (2009).

63 In this connection see my 'Is There an Antitrust Antidote, above at note $55,307-8$ where there are quotations.

64 K. Jorda, 'The Role of Intellectual Property in Economic, Social and Cultural Development' in WIPO Worldwide Academy, International Conference on Intellectual Property Education and Training, New Delhi, Geneva, (2002) 45, 57.

65 See Lerner, above at note 4, 30. 
extra plants, factories, production lines, and to go down the learning curve; rather the invention, once secured, may reach the market overnight. This point may be illustrated by an example drawn from the here relevant field of genetic engineering. The only difficult thing in devising an emergency treatment for a heart attack based on tissue plasminogen activator (TPA), a known substance produced by the body to help the heart to re-vascularize in the first hours after the event, was to identify the DNA sequence which codes for this protein with a view to synthetically producing the protein itself and administering it to early-stage patients. Once the TPA sequence is identified, it becomes quite easy to synthesize the desired amount of this protein for treatment of heart attacks. ${ }^{66}$

So, it may be argued - and it has been argued - that, to recoup the kind of investment in research (rather than development) which is currently required in cutting-edge technological innovation full exclusivity may not be really needed all the time. Protection under liability rules may still (sometimes) do the trick. ${ }^{67}$

May be so. The reverse is also possibly true and probably more likely: when disembodied knowledge enables immediate access to market, this is a good reason for innovators to demand that the protection is moved upstream, rather than to give up on exclusivity. Indeed, if the trajectory from innovation to market gets shorter for innovators, the same applies to their competitors. To go back to our TPA example, once the DNA sequence is identified, this piece of scientific knowledge is immediately available not only to the innovator, but also to all the other entities who may wish to manufacture and sell the protein. Here the non-IP competitive advantage de facto given by lead-time is not available. This simple fact explains why life science operators have been clamoring for patent protection; ${ }^{68}$ the political economy of the legislative process explains why they have been so successful. ${ }^{69}$

My impression, however, is that there is a different explanation why the edges of exclusivity are currently been rounded off, by legislatures,

66 See U. Schatz, 'Patentability of Genetic Engineering Inventions in European Patent Office Practice', 29 IIC (1999), 2, 3.

67 For a similar point see J. H. Reichman, 'Of Green Tulips and Legal Kudzu: Repackaging Rights in Subpatentable Innovation' 53 Vanderbilt L. Rev. (2000), 1743.

68 For an early account see my 'La direttiva sul brevetto biotecnologico: efficienza allocativa, equità e potere', XLII Quaderni di sociologia (1998), 166.

69 See M. Olson, The Logic of Collective Action: Public Goods and the Theory of Groups, Harvard, (1965). 
by courts and also by private rightholders. This explanation is not related - except in a quite roundabout way $-^{70}$ to the (otherwise probably accurate) point made about the decrease in the amount of investment required in the cycle which leads from research to development and marketing; and would seem to apply not only to technological innovation but also to other forms of creativity, including - once again - copyrightprotected creativity. The explanation may be encapsulated in just a few words: in the current environment of creativity and innovation exclusivity tends to backfire. This point needs a to be belabored a little bit, as I will try to do shortly.

\section{WHEN DOES EXCLUSIVITY IN IP PROTECTION BACKFIRE?}

To make my point I will take a few examples and see which inferences we may draw from them.

\section{A. Patent Wars}

In the last few years, we have been witnessing to an extraordinary increase in patent litigation. ${ }^{71}$ There are of course a number of factors which account for this development. An important factor has to do with the grant of an increasing number of patents which do not claim the end product but discrete complementary inputs, which may be very minor in their contribution to the end product but still may be innovative enough to receive patent or IP protection. That even discrete complementary inputs may receive IP protection is not a novel feature of our systems; rather, this feature has been there all the time and has on other occasions played an important role both in business decisions and public policy

\footnotetext{
70 On which see below notes 73-77 and accompanying text.

71 A. B. Jaffe and J. Lerner, Innovation and Its Discontents: How our Broken Patent System is Endangering Innovation and Progress and What to Do About It, Princeton, (2006) and before them J. O. Lanjouw and J. Lerner, 'Tilting the Table? The Predatory Use of Preliminary Injunctions', 44 J.L. \& Econ. (2001), 573 have collated evidence on increase of patent litigation. See also J. Bessen and M. Meurer, Patent Failure: How Judges, Bureaucrats, and Lawyers Put Innovators At Risk, Princeton, (2008); D. L. Burk-Mark, A. Lemley, The Patent Crisis and How the Courts Can Solve It, Chicago-London, (2009) and for a review of literature Rimmer, above at note 61, 197.
} 
making. ${ }^{72}$ What has changed in recent decades is the extent to which such discrete complementary (and often minuscule) inputs may receive protection. The shift towards 'upstream' protection we have witnessed to in recent years ${ }^{73}$ has inordinately multiplied the number of entities, be they small discrete inputs of a larger product or fragments of a larger work, which may attract IP protection. It would thus appear that an individual cell phone may be protected by an inordinate number of separate IP rights. Now, when exclusive IP rights are available over multiple, discrete complementary (and often minuscule) inputs, rather than over end products, exclusivity tends to 'backfire'. When the holders of IP rights over complementary items are more than two, the transaction costs required for their joint exploitations grow exponentially, exactly as anticipated a long time ago by law and economics scholarship. ${ }^{74}$ Sequential monopoly issues arise; strategic behavior, including holdouts, tends to become the norm. ${ }^{75}$ Downstream innovation and creativity suffer, as predicted by theorists of the tragedy of the anti-commons ${ }^{76}$ and now widely documented by patent wars in the fields as diverse as ITC and green technology. ${ }^{77}$

\section{A brief detour on anti-commons theory}

As we have come across the theory of the tragedy of anti-commons, we may as well see what this - now popular- narrative has in store for us. We may begin to understand what the anti-commons argument means by considering it turns on its head the theory of the tragedy of the commons, originally advocated by an important article written in the early 60 s by a scientist, Garrett Hardin. In the Middle Ages, he had remarked, stretches

72 Merges, above at note 60,1342 , dealing with pooling as a response to conflicting patents on the basic building blocks for car and airplane industries.

73 See above notes 68-69 and corresponding text.

74 G. Calabresi and A. D. Melamed, 'Property Rules, Liability Rules and Inalienability: One View of the Cathedral', 85 Harvard L. Rev. (1972), 1089, 1127.

75 See C. Long, 'Information Costs in Patent and Copyright', 90 Virginia L. $R$. (2004), 465 and J. Bessen and E. Maskin, Sequential Innovation, Patents, and Imitation, Working Paper, Department of Economics, Massachusetts Institute of Technology, No. 00-01, January (2000), <http://dspace.mit.edu/bitstream/handle/ 1721.1/64176/sequentialinnova00bess.pdf?sequence=1> accessed 26 April 2014.

76 For an early account see M. A. Heller, 'The Tragedy of the Anticommons: Property in the Transition from Marx to Markets', 111 Harvard L. Rev. (1998), 111.

77 See M. Rimmer, Intellectual Property and Climate Change quoted above at note $61,197$. 
of land held in common by the local population were gradually depleted, as they were overgrazed (too much cattle grazing over the same fields) and deforested (too much wood extracted from the communal woods). In his account, optimal allocation was restored by enclosures such as the ones that took place in England since the sixteenth century. As soon as individual owners obtained undivided title over the land, depletion stopped: an individual owner would not disregard the long-term implications of depletion, as he himself would bear all the future costs of inefficient use; while, as long as short-term benefits were reaped by the commoners individually while the corresponding costs were borne by the whole community, the same long-term costs were disregarded. A similar situation applied to fisheries, which were running - and indeed still are running, in spite of quotas - the risk of depletion of stock as each fishing fleet ignores the long-term implications of overfishing. According to Hardin, in this perspective, the commons, appealing as they may sound to the romantics and to the left leaning, in reality are a tragedy; their opposite number, property rights, are efficient. ${ }^{78}$

One may wonder what this all has to do with ICT and biotech patents and more generally with IP. The connection may become a bit clearer when I mention that about the same year one of the most powerful minds behind the law and economics movement, Professor Ronald Coase, was bent on proving ${ }^{79}$ that, by protecting the resource with a property right, the law combines the static efficiency Garret Hardin was talking about with dynamic efficiency, as it enables market transactions whereby the resource may move to its highest valued use. From there the argument migrated to intellectual property rights, bringing a forceful argument to bolster the case for the incentive role of exclusivity we earlier discussed: ${ }^{80}$ protection of IPRs by means of property rights contributes to the optimal allocation of resources. The matter gets a bit more complex and controversial - when the case is made that novel forms of innovation, such as biotechnology, should also be protected by means of patent rights. It was argued however that fundamental research concerning the double helix may well have originated within the commons of the public, academic research; but when it came to reaping the fruits of the tree of

78 For a classical account of this position see H. Demsetz, 'Toward a Theory of Property Rights', American Economic Review (1967), 347.

79 See R. Coase, 'The Problem of Social Cost', 3 Journal of Law and Economics 1 (1960).

80 For a brilliant treatment see R. P. Merges, 'Of Property Rules, Coase and Intellectual Property Law’, 94 Colum. L. Rev. (1994), 2655. 
knowledge, property rights, not the commons, would be the most appropriate regime. ${ }^{81}$

Now, this line of argument is, as I was saying, literally turned on its head by those scholars who maintain that protecting innovation by means of property rights may lead to a tragedy opposite and symmetrical to the one elucidated by Garrett Hardin, the tragedy of the anti-commons; and that this may specially be the case in novel fields like digital technology and - indeed - genetic engineering. According to this viewpoint, the tragic features are two. We just dealt with the first one: when IP monopoly is granted not on competing end products, but on many discrete, minuscule complementary inputs which may be incorporated in several end products, transaction costs concerning the authorization to combine several IP-protected inputs into a new product or service are bound to exponentially increase and negotiations, which in principle should lead to the most efficient use of the IP resource, are likely to break down. Exactly for the reasons we just saw.

While this first limb of the theory of the tragedy of the anti-commons is another way to tell the same tale I just went through, there is a second limb to this same theory which gives an additional contribution to our understanding of the reasons why exclusivity may in fact backfire. According to the theory of the tragedy of anti-commons, when IP protection is granted on discrete components which go into an end product, propertization by means of exclusivity may have another kind of adverse impact, by restricting the free flow of information and knowledge which welfare optimality would leave in the public domain. Let us look more closely at this second issue from the vantage point of innovation in agriculture and medicine.

\section{B. Patent Embargos}

While traditionally basic scientific research in agriculture and medicine had been open and the information resources widely shared by the scientific community, propertization of research outcomes through the grant of patents on agricultural and medical innovation as initiated in the late 70s or early 80 s is seen as apt to build up barriers to the access and re-use of information and of information-carrying assets and is thus

81 An offspring of this conception was the adoption of rules providing incentives to patenting by Universities, such as the US Bayh-Dole Act of 1980, Publ. L. No. 96-517, 94 Stat. 3015 (codified as amended at 35 USA $\S$ 200-212 (2000)), for an assessment of which see R. R. Nelson, 'Observations on the Post-Bayh-Dole Rise of Patenting at American Universities', IPQ (2001), 1.

Columns Design XML Ltd / Job: Drahos-Kritika_Essays_on_Intellectual_Property-x / Division: 06-ch6_tracked /Pg. Position: 34 / Date: 
deemed liable to endanger the enormous benefits which scientific cooperation entails.

Let us examine more closely the reasons that usually are given to account for the emergence of this second limb of the tragedy of the anti-commons. Once it is established that research outputs may attract IP protection, it is quite predictable that, in the new context, no institution would engage in investment unless it could obtain a legal monopoly on its research outputs, exactly as posited by the supporters of patent protection. However, as several commentators have noted, propertization may also severely adverse impact upstream and downstream on the innovation process.

Upstream the very possibility of obtaining property rights over research outcomes suggests to all the players that it is advisable for them to avoid organizational arrangements which entail any sharing of information with third parties, as disclosure of patentable information to third parties may destroy novelty. Therefore, if the grant of a patent is possible, all interim steps, including materials obtained in the preliminary stages of a research trial or information pertaining thereto, tend not to cross the door of the laboratory, to avoid making disclosures which may prevent patentability and give leads to potential competitors. Even presentation of ongoing research at academic meetings and publication of research findings before patent filings recede for exactly the same reasons. Exchanges may to some extent continue, e.g. in terms of material transfer agreements; but then they tend to be governed by restrictive terms intended to reserve entitlement over downstream innovation to the benefit of the transferor. ${ }^{82}$ In turn, the process may trigger domino effects: any initial move by one of the players to obtain exclusive right and to leverage them to secure contractual privileges is bound to trigger defensive reactions by similarly situated players. ${ }^{83}$

An increasing number of commentators have therefore expressed fears that patent protection, when applied to agricultural, medical and genetic engineering innovation, may ultimately entail costs greater than the expected benefits. While in principle property rights may be seen as an efficient tool to induce innovation and enhance market based exchanges over it, it is often feared that the specificity of some areas, including

82 E. Bertacchini, 'Contractually Constructed Research Commons: a Critical Economic Appraisal: A Critical Economic Appraisal' in M. Dulong de Rosnay and J.C. De Martin (eds), The Digital Public Domain, Cambridge (2012), 95, <http://www.openbookpublishers.com/reader/93> accessed 26 April 2014.

83 Ibid., 102. 
biomedical research and biotech, may lead to the adoption of strategic behavior and to an unacceptable increase of transaction costs. ${ }^{84}$

\section{Matching Data Sets}

It would appear that the issues just raised do not concern only technological innovation. Also digital resources (e.g. digital data sets), as we noted, typically form multiple complementary inputs for composite downstream products and services, ${ }^{85}$ which, in turn, may form the basis for additional downstream innovation and moreover tend to be combined in ways which are ex ante unpredictable. ${ }^{86}$ That IP protection, in particular of these special digital resources which are data sets held by governments (Public Sector Information), is bound to generate anticommons problems is therefore predicted by theory and - unfortunately confirmed in practice.

\section{WHERE DO WE GO FROM HERE?}

We are now in a position to combine the intermediate results reached in our attempt to reply to the question whether the incentive provided by exclusivity to generate creativity and technological innovation is still needed in the current environment.

\section{A. The Diagnosis}

Our conclusions were that to a large extent cooperation rather than the incentive provided by exclusivity accounts for creativity in the current digital environment, even though this finding would seem to apply only to digital-network driven creativity and not to 'legacy' sectors, where the long route still is alive and - up to a point - well and the incentive provided by exclusivity is still successfully at work. We have also seen that these (tentative) findings concern only creativity, i.e. works and products which are candidate to copyright or copyright-like protection. ${ }^{87}$

84 M. A. Heller and R. S. Eisenberg, 'Can Patents Deter Innovation? The Anticommons in Biomedical Research', 280 Science 698 (1998).

85 See above section III.C In literature see Newbery, Bently and Pollock, quoted above at note 33, 21 .

86 See above the second remark in section III.

87 An interesting question, which can at this stage only be asked but not yet (even tentatively) be answered is whether the new intermediaries and platforms 
For technological innovation, which is apt to trigger patent protection and similar 'industrial' exclusivity titles, the findings would appear to be even more intricate. In this connection we found that, while the erosion of the role of exclusivity as an incentive would not appear to have taken place, still the edges of exclusivity tend to be rounded off either by agreements between rightholders ('private ordering') or by fiat of courts and legislatures (which often morph property rights into liability-rule protected titles). Among the possible reasons for this 'rounding off of the edges' of exclusivity one was identified which is germane to the difficulties identified by theorists of the anti-commons tragedy: exclusivity may backfire when its protects discrete complementary inputs rather than end products, as it tends to happen more and more often in the current innovation environment.

\section{B. The Task Before Us}

If this diagnosis is accurate, then the task before us is daunting. Only one thing is crystal clear: that the set of rules which prevailed in the last few centuries are no longer up to the task of delivering the amount of the peculiar public goods we understand under the labels of creativity and innovation which is optimal for society. The current system is broken down. It still gives full-fledged and unmitigated exclusivity even in these areas (digital network driven creativity) where the incentive of exclusivity is no longer needed; 88 moreover, by giving full-fledged exclusivity even to discrete fragments or inputs, it creates obstacles to that very cooperation between peers which has in the meantime emerged as a veritable engine for creativity along the short route.

While the incentive given by exclusivity still proves to be essential in several 'legacy' segments of creativity and along the whole spectrum of technological innovation, moves to locate IP protection upstream, to protect discrete inputs or fragments of innovation and creativity, end up

briefly discussed in section III.E require exclusivity as an incentive for their contribution to creativity. At this stage I would note that: (i) new intermediaries and platforms have been conducting crusades to 'free' content belonging to creators and businesses operating along the long route, as exemplified by the Google books wars (the epilogue of which is to be found now in US District Court, Southern District of New York 14 November, 2013, Authors Guild Inc. et al. $v$ Google Inc.); (ii) while, at the same time, they seem to be rather vocally claiming for exclusivity over some of the creations they have been contributing; so that (iii) the question arises as to the revocability of permission of IP belonging to them (on which see sections III.E and VII.D).

88 Section III.D. 
granting exclusivity exactly where exclusionary power in the hand of rightholders backfires. The problem is only in part addressed by moves to convert property rights into liability rules by means of private ordering and by legislative or court intervention, which, while mitigating the adverse impact of generalization of exclusivity, still leave the greatest part of the anti-commons tragedy unsolved.

\section{An Agenda for Future Action}

This unfortunate situation opens up an immense field of research in the quest for ways to fix our broken system of creativity and innovation. While it may be said that the research to redesign the legal rules is well under way in a number of areas, and in this context I will not try to engage in the task of reviewing the literature which has proposed the design of a more functional system to promote creativity and technological innovation. ${ }^{89}$ Rather, I will confine myself to two - indeed very ambitious - tasks, one general and the other specific.

The first task consists of the effort to draw a tentative map of the elementary components, or building blocks, which would appear to go into the design of rules appropriate to the new paradigm of creativity and innovation.

An interesting question concerns the identification of the players who should be involved in the re-design. It is not altogether clear what are the roles to be played in this connection by nation States, regional entities and international organizations, on the one side, and by private players, on the other. On the one hand, an adequate recognition of the significance of private ordering to untie the knots tied by 'ancient regulators' should make us wary of putting too much hope on the contribution which can come from sovereigns. ${ }^{90}$

89 See however Libertini, quoted above at note 1, providing a large number of fresh proposal as well as an extensive review of the literature; in connection with technological innovation see also Antonelli, above at note 2.

90 This does not mean that ancient sovereigns could not improve their performance in this area by means of a modicum of rethinking of their role. In this connection, it may be mentioned that a leading research institution (namely the Max Planck Institute for Intellectual Property and Competition Law) is initiating consideration of research on one of the most crucial topics in the area: the advisability of a shift from the understanding (by ancient regulators) of IP negotiations as trade tools, intended to support the interest of the IP exporting industries located in a given territory, to the concept that a novel approach is required which takes into account global interdependency, global power shifts and the (possibly negative) repercussions on domestic creativity and innovation 
On the other hand we cannot afford to forget that there is an additional factor to be incorporated into the equation: the rising role of platforms, the 'new intermediaries', which, as earlier noted, ${ }^{91}$ would seem to be thriving and expanding at a phenomenal rate in the current, very nuanced, evolutionary stage of our economies and societies which at the same time takes the shape of the twilight for legacy business and of the dawn for network-driven cooperation. I do harbor qualms over the possibility that private ordering may adequately take care of the power which is being accumulated in the hands of these novel players; so that it is to be expected that the issues arising out of the - market and political - power of new intermediaries shall require some form or other of intervention from sovereigns. Let me underline that the issue is crucial, if our societies desire to avoid that the flourishing of network-driven cooperation ends up being sucked up by the exuberance - and belligerence - of platforms.

It is submitted that the identification of the appropriate level where legal change may take place is best left at a stage where the building blocks of the new system have been at least tentatively identified. Indeed, it would appear that there is no such a thing as a theory of the optimal fora for legal change. ${ }^{92}$

While most, if not all, the components which go into this map have to do, as we shall presently see, with the re-shuffling of cards which belong to the traditional IP stack, ${ }^{93}$ the second task goes beyond this perimeter as it extends to an area of private law which lies at the extreme boundaries of the toolkit of IP lawyers. In this context I will address an issue which has to do with the private law corollaries of the new landscape of creativity and innovation and which may be summarized as follows: if we assume for a moment that, in particular in the area of creativity, and at least in those segments which are driven by digital networks, the tools of cooperation have replaced the incentive hitherto provided by exclusivity, then what are the implications of this shift in

of moves adopted to further the increase of IP protection overseas. This approach deserves the greatest attention.

91 Section III.E.

92 See below, sections VII.E and IX.

93 Which is not to say that the re-shuffling may not lead to results which are at times quite radical, to the point that at some stage the question arises whether we should persist in using the term 'Intellectual Property' at all (see also for references Libertini, quoted above at note 1). In fact, were I still to teach for a substantial period of time my introductory course on IP, I would propose to rebrand it 'Intellectual Property \& Commons'. 
terms of the mechanisms provided by private law to carry out the transactions which enable cooperation and the enjoyment of the fruits of cooperation by the public? Here we do not have to build from scratch, as we have the possibility of working on the basis of the growing body of case law, legislation and literature concerning digital licenses of the second variety. ${ }^{94}$ However, there is still a vast number of conceptual and operational issues that require fresh thought, which go from the relationship between digital licenses and contracts to the role played by unilateral, non-contractual acts in our legal systems.

\section{The Components of the IP Governance of the New Paradigm. Towards a Two-Sectors System?}

Before going into these private law corollaries of the new paradigm, however, we should first try, as anticipated, to map the components which go into the IP governance of this paradigm itself. As I will presently try to do, in an admittedly cursory and shorthand and therefore unsatisfactory fashion..$^{95}$

To begin with, any effort to design a system intended to secure the appropriate level of creativity and innovation in the current environment must accept that the system itself requires that two separate mechanisms for promoting the desired goals are in place and are capable of functioning together and coexist.

Full-fledged exclusivity would still play a crucial role in the first mechanism. The incentive provided by it is still required at least where a substantial amount of outlay and investment is required to reach the market. This is still the case for the 'legacy' segments of copyright industries and for many of the areas of technological innovation.

This does not mean that we may accept the continued existence of full-fledged exclusivity across the board. First, full-fledged, unmitigated exclusivity is no longer necessary where exclusivity does not provide an incentive to creativity. Here exclusivity may still be necessary, but to a much lesser degree: to the extent as it may be used as a tool to open, rather than to restrict. ${ }^{96}$ This is where the second mechanism comes in.

94 See above at section III.B.1.

95 For additional references see Antonelli, above at note 2 and my paper 'Consume and Share: Making Copyright Fit for the Digital Agenda' in C. Geiger (ed), Constructing European Intellectual Property. Achievements and New Perspectives, Cheltenham, (2013), 314.

96 Section III.B. 
Also where full-fledged exclusivity is still required, we have to take into account that this more expansive form of exclusivity requires some kind of rounding off at the edges. This is particularly necessary, because in our current environment IP protection has moved upstream, ${ }^{97}$ maximizing the risk that exclusivity backfires and hampers the possibility of market transactions enabling the combination of complementary discrete inputs.

The governance of the new IP system should be based on three pillars.

\section{The first pillar of the two-sectors system: Enabling extensive resort to private ordering}

In the past, private ordering has been crucial in sorting out many of the bottlenecks arising out of the current system of IP protection. Today, the role of private ordering should be expanded in the area of creativity, to fully take advantage of the superiority of decentralized, bottom-up choices over top-down regulation. Enabling private ordering requires a legislative change giving all the players an initial choice: they may opt in to the full-fledged exclusivity conferred by copyright protection, if subject matter and access requirement are met, simply by registering their work in a global digital registry; they may opt out of any form of protection, if they wish to relinquish their creations and innovations to the public domain. Between these two extremes a default rule should apply, which entails the modicum of exclusivity required to open rather than to restrict. We already referred earlier to this sort of lesser exclusivity; ${ }^{8}$ I note here that a default rule providing for it - in the spirit of what I referred half a decade ago as Copyright 2.0 -99 is essential for private ordering. This is so because, as noted earlier, ${ }^{100}$ a minimum of IP protection is required as a basis to enforce compliance with licensing conditions; and open licensing, mandating free and unfettered re-use of the resource, would remain pointless and without effect, if compliance was not enforceable.

I am often asked what would be the advantages of moving to Copyright 2.0 as a default rule. The reply to the question is pretty straightforward. We would have enormous benefits in both sectors.

First, on the basis of the global digital registry it would be extremely easy to establish which digital works are free for re-use. This would be

97 Section IV.B.

98 Section III.D

99 See my paper 'Copyright Policies for Digital Libraries in the Context of the i2010 Strategy' quoted above at note 2.

100 Section III.D. 
an enormous boon not only for downstream creativity but also for the daunting task we have to plan and enable digital literacy of the next generations. ${ }^{101}$

Second, a global digital registry would enormously decrease transaction costs. E.g. all the difficulties we link to orphan works would disappear. Either they are out of the registry; and then they are freely re-usable; or they are in it, and then they are not orphan.

To cut a long story short: in this field, not only is exclusivity no longer (always) required, but adopting a system which takes this into account would entail such collateral benefits that it is to be expected that the push towards change will at some point become irresistible.

\section{The second pillar of the two-sectors system: (More) extensive resort to liability rules}

It has been noted that providing for a default rule limited to the field of copyright as just suggested would be of no avail if the working of the default rule was not accompanied by some device able to mitigate the adverse downstream effect that full-fledged exclusivity, in connection with technological innovation and where copyright protection is opted in, might still entail if not appropriately contained. ${ }^{102}$ This is certainly a point well taken: arrangements in one sector are bound to be of limited help towards revitalizing the flow of creativity and innovation, unless they are appropriately interlinked with the working of the other sector.

\footnotetext{
101 Consider that in the near future education, from the nursery stage onwards, will no longer based exclusively on printed text; that the basic skills will consist not only in reading, writing and mathematical skills, but in programming and remixing digital material (text, sound, images). Currently most digital resources are locked in old 'all rights reserved copyright' and thus are not amenable to teaching and learning, except when fair uses apply; which is not often the case when we talk about digital resources. In the past, copyright did not stand in the way of reading, translating and quoting analogue text. However, old 'all rights reserved' copyright would make using digital works in the educational process a nightmare. Copyright 2.0 may be the way out of this conundrum, by serving as the repository for raw materials which will enable the new generations to acquire skills equivalent to the ones we have been able to comfortably acquire in the past. For a treatment of this, indeed crucial, issue see my 'Le utilizzazioni libere dell'IP nei social network', in AIDA 295 (2011), 299-300 and the important remarks by L. Lessig, 'Creative Economies', Mich. St. L. Rev. 33 (2006). See also L. Lessig, Remix quoted above at note 27, 51.

102 I am indebted to Fabio Montobbio for raising this point during the discussion of an earlier version of this paper at a seminar held in Turin 12 June 2013 at the Department of Economics.
} 
This may be accomplished in a number of ways. The first one has just been mentioned: paving the way to private ordering. Indeed, as private ordering has been able in the past to untangle several IP knots, it holds in itself the possibility of opening up many of the roadblocks ahead, by facilitating contracting into liability (including enabling the emergence of contractually reconstructed commons in cutting-edge areas of technological innovation). ${ }^{103}$ Second, the conventional tools to convert property rules into liability rules (compulsory licensing, antitrust remedies to refusals to deal in IP) ${ }^{104}$ should be fine-tuned. ${ }^{105}$ Third, the mechanism of limitations and exceptions should be rethought, in a number of ways which, as I argued elsewhere, ${ }^{106}$ include the establishing of the boundaries between the old and the new continent of creativity and innovation and the flow of resources from the former to the latter and vice versa. ${ }^{107}$

Important as they may be, all these ways to rethink the respective costs and benefits of property and liability rules finally amount to small change

103 As proposed by Reichman and Uhlir and by Rai, Reichman, Uhlir and Crossman, bothabove note 53 .

104 On which see section IV.A; for a similar point Libertini, quoted above at note 1 , advocating the resort to the imposition of wide cooperation duties on patentees.

105 There should be scope for jurisdictional variations in the administration of antitrust remedies, for the reasons I explored in 'Is There an Antitrust Antidote' above at note 55,334 .

The imposition of liability rules, including ex post and ad hoc remedies, such as the ones under antitrust rules, have long been exposed to the (quite reasonable) criticism that they may destroy the incentive to innovate. In this regard recent economic research seems to be leading to the conclusion that a mechanism may be devised which, by combining compulsory licensing with appropriate remuneration (royalties) levels, set under a set of pre-determined rules, may strive towards optimality by minimizing both the loss of incentives for patentees and the adverse downstream effects: see Antonelli, above at note 2, $165-72$.

106 In my 'IP Limitations and Exceptions and Competition: a Normative Assessment', AIDA (2013), 306, 314-15.

107 This is not an exhaustive list, though. A notion which would appear to be worth exploring lies in the concept of immunity, which could be employed to guarantee a non-infringing status to production and sale of germplasm which is the original basis for follow on genetic innovation. For details of this concept, which would avoid the difficulties involved in conferring IP protection on contributions which go back to remote times and cannot be attributed to specific individuals or entities, see my 'The Interface between Intellectual Property and International Trade: the TRIPs Agreement', Italian Intellectual Property (2002), 29, 43-44. 
if compared to the really core issue, whether judges have the power and the duty to engage in a balancing exercise when deciding whether to grant injunction or award damages for IP violation. To cut a long story short, my idea here is that the US judges have it right; EU Courts do not. ${ }^{108}$ Except, of course, that European judges' hands are tied up by old-fashioned rules which bind them to the idea that exclusivity is always protected by a property rule. May be the time has come to rethink just this essential notion.

\section{The third pillar of the two-sectors system: Infrastructure}

There are a number of design principles which must be followed in the design of an agenda for future action to ensure the robustness of the two-sectors system I propose. As we just saw, private ordering and bottom-up legal innovation may do a lot; but must be complemented and buttressed by appropriate intervention of sovereigns. ${ }^{109}$ Let me sketch out a very tentative list, which tries to capture the idea that the third paradigm must rest on solid foundations:

(i) net neutrality. The web constitutes a global public good available for both sectors; and, if it is to retain its capability to function as a engine of innovation, it has to retain the end-to-end design. ${ }^{110}$

(ii) ISP providers are intermediaries of crucial importance, straddling between different categories of users of the net. Whatever liability may be imposed on them must take into account that their job is not only to enable price-based market transactions but also to enable digital-network driven cooperation. Rules which freeze their freedom to experiment in response to the needs of non-market players should pass a high level of scrutiny before being adopted. ${ }^{111}$

108 Compare eBay Inc. v MercExchange, LLC, 547 U.S. 388 (2006) to the unfortunate decision of the ECJ 27 April 2006, in Case C-145/05, Levi Strauss \& Co. v Casucci S.p.A. (2006) ECR, I, 3703, case "mouette". It would seem that more recent provisions, such as Art. 62 of the Agreement on a Unified Patent Court signed February 19, 2013, finally gives European judges more leeway.

109 Possibly in forms different from the ones which lead 'ancient regulators' to the many failures detailed by D. R. Johnson and D. G. Post, 'Law and Borders: The Rise of Law in Cyberspace', 48 Stanford Law Review (1996), 1367.

110 The literature on net neutrality is immense: see however Jack L. Goldsmith and $\mathrm{T}$. Wu, Who Controls the Internet? Illusions of a Borderless World, Oxford, (2006).

111 See among the many M. Leistner, 'Common Principles of Secondary Liability?' in A. Ohly (ed.), Common Principles of European Intellectual Property Law, Tübingen, (2012), 117; N. Suzor and B. Fitzgerald, 'The 
(iii) in specific connection with copyright and copyright-like sectors, collective rights management organizations (CRMOs) have traditionally operated as intermediaries between rightholders and users helping to negotiate the long route which leads from the former to the latter. In the current digital environment they should expand their mission to act as intermediaries also on behalf of creators operating along the short route, thereby avoiding the risk of being doomed to irrelevance. ${ }^{112}$

(iv) competition law also has an important role to play in setting the rules of the game for the coexistence of the third paradigm of creativity and innovation with more traditional forms of doing business. No doubt this is particularly true in that intermediate area where traditional businesses' price-based market transactions meet the 'hybrid' business models favored by creators operating along the short route. Here, one issue is how to guarantee the creation of a level playing field between players which, while operating in accordance with different sets of rules, end up offering competing goods and services to the same market or, at least, to markets which to a large extent overlap, as shown by the now historic competitive relationship between proprietary software and FOSS. ${ }^{113}$ However, we should pay close, very close attention to another emerging area of competition and conflict: the one at the intersection between the two sectors which make out the system we have been dealing with here and the new, aggressive actors which are grabbing a larger and larger slice of the act, that is 'new intermediaries' and platforms. Of course, we do not know much as yet of the forms which the looming confrontation will take. We know however that 'digital native businesses' as the new intermediaries possess a number of features - from zero marginal costs, positive network externalities, economies of scale (and of scalability) and of scope -114 which will

Legitimacy of Graduated Response Schemes in Copyright Law' in 34 University of New South Wales Journal of Law (2011), 1.

112 I tried to develop the argument in my 'Individual and collective management of copyright in a digital environment' quoted above at note 10, 313.

113 For a forceful - if biased - account see R. A. Epstein, 'Why Open Source is Unsustainable' Financial Times (London, 21 October 2004). This rather extreme position may contain a grain of truth: we cannot forget that in dealing with information distributed modes of production may at times have a distinctive competitive advantage over markets and hierarchies (see section III.C).

114 See section III.E. 
throw up challenges which to a large extent have to be dealt with by the tools of antitrust.

(v) an expansive public domain should be secured, to guarantee access to a vast pool of genetic resources, data, information and knowledge, to be freely re-used and recombined by agents in both sectors; ${ }^{115}$

(vi) the existence of shared resources and the recognition of the importance of the goal of enabling the interactions between resources belonging to the two different sectors is at the basis for the growing concerns for interoperability. ${ }^{116}$

This is clearly an incomplete and sketchy list of the infrastructural requirements which are needed to ensure an equitable, efficient and sustainable interaction between the two sectors. Nor am I sure whether their conceptualization may be best organized along the lines proposed by theorists of the knowledge commons ${ }^{117}$ or by literature on the increasing role of infrastructure. ${ }^{118}$ While a lot of work still is required to start focusing on the conceptual framework necessary in this connection, it would appear to me that the time has come to re-conceptualize the interaction between the old and the new continents of creativity and innovation.

115 A good example of a (partially) successful global initiative to preserve biodiversity and guarantee access to plant genetic resources is provided by the (FAO) International Treaty on Plant Genetic Resources for Food and Agriculture on which see L. R. Helfer, 'Using Intellectual Property Rights to Preserve the Global Genetic Commons: the International Treaty on Plant Genetic Resources for Food and Agriculture' in K. Maskus and J. H. Reichman (eds), International Public Goods and Transfer of Technology under a Globalized Intellectual Property Regime, Cambridge, (2005).

116 See in this connection J. Palfrey and U. Gasser, 'Interop. The Promise and Perils of Highly Interconnected Systems', New York, (2012).

117 See C. Hess and E. Ostrom, 'Introduction: An Overview of the Knowledge Commons' in C. Hess and E. Ostrom (eds), Understanding Knowledge as a Commons. From Theory to Practice, Cambridge-London, (2007), 3. In this connection, I am not prepared to share the critical attitude of Libertini, quoted above at note 1, towards knowledge commons theory, which I see as intent rather on building governance rules for what I here call infrastructure for (new and old) creativity and innovation rather than on proposing a sweeping abolition of any kind of IP.

118 Frischmann, above at note 33, 917. 


\section{An agenda for legal change}

Defective and incomplete as it may be, this list of components enables us to start visualizing the forum - or rather: the fora - where legal change may conceivably be initiated and advanced. Clearly, the provision of global public goods is hardly a matter for private actors and nation States: the setting up of a system for the preservation and enhancement of global genetic resources for food and agriculture requires action at the global intergovernmental level. However, it would appear that in some cases legal change is best initiated at the regional level. As I argued elsewhere, ${ }^{119}$ the EU does have the right incentives and the prestige to take an initiative to replace the 1886 Berne Convention on copyright with a Berne II initiative, adopting the Copyright 2.0 approach which is becoming more and more mainstream.

In other regards, the optimal contribution to legal change may come from regulatory competition. One would imagine that in this regard the various antitrust authorities operating around the globe and attuned to the specific needs of their constituencies may turn out once more to be the laboratories of legal innovation which were hailed by Justice Brandeis in his dissent in Liebmann. ${ }^{120}$ An important contribution from regional antitrust authorities is to be expected in both the areas which I mentioned as relevant to make the third paradigm of creativity and innovation work: the creation of a level playing field between digitalnetwork driven cooperation and legacy businesses, as well as the taming of the 'animal spirits' of new intermediaries and platforms.

However, the importance of bottom-up action by private players, in particular by resorting to private ordering to accomplish via voluntary arrangements and decentralized decisions the very optimality which regulators botched in recent decades, can hardly be overestimated. If one is allowed once in a while to say something slightly over the top, then I

119 In 'Consume and Share: Making Copyright Fit for the Digital Agenda' quoted above at note 95, 322 .

120 By combining Justice Brandeis's two famous dissents, it is easy to see that regulatory competition may oscillate between two extremes. Either the different competing jurisdictions are seen as laboratories experimenting diverse legal rules to strike whatever balance between confliction interests appears appropriate to the relevant constituencies: New State Ice Corp. v Liebmann, 285 U.S. 262, 311 (1932). Or, in the alternative, they may engage in a 'race of laxity', Louis K. Liggett v Lee, 288 U.S., 517, 557-9 (1933), to favor concentrated interests (typically: business interests) or cut down on dispersed interests (typically: outside investors', consumers'). Until we know which outcome is to prevail, we cannot decide whether regulatory competition is a good thing or a bad one.

Columns Design XML Ltd / Job: Drahos-Kritika_Essays_on_Intellectual_Property-x / Division: 06-ch6_tracked /Pg. Position: 47 / Date: 
should say that, while we have reasons to fear that this time the lobby of horse driven carriage owners will prevail over railways, the hope that this will not be the case may be placed more in the hands of the users of the IP-system, which ultimately means the public, than in the wisdom of sovereigns and international organizations.

\section{PRIVATE-LAW TOOLS ENABLING DIGITAL-NETWORK DRIVEN COOPERATION: A THEORETICAL FRAMEWORK}

One component of the two sector-system which I did not elaborate on, even though it has a crucial importance in the design of the system, as I earlier indicated, ${ }^{121}$ is the identification of the private law tools enabling digital-network driven cooperation. Let us now turn to this special - if rather expansive - issue.

\section{A. From Goods to Acts}

This is quite a jump. IP lawyers usually deal with goods. These may be either the ideal entity (the corpus mysticum we referred to earlier) or the corpora mechanica, be they tangible or intangible, in which the former is incorporated. The attention devoted by IP lawyers to transactions over IP is somewhat muted. Assignment and licensing concerning IP rights, as well as cooperative arrangements among rightholders and between rightholders and users, do play a certain role in their landscape; ${ }^{122}$ less so transactions concerning IP-incorporating products and services. After all, who would thing of engaging in extensive research and discussion of sales of Coca Cola bottles, of brakes and of books, even though some corners of these transactions from time to time do deserve scrutiny from an IP perspective. ${ }^{123}$ In the last few decades, this attitude has in part changed. It has dawned on us that particularly in one corner of our

121 At section VI.C.

122 As shown, of course, by the increased attention to the forms of 'contracting into liability' we earlier referred to: see the important contribution by Merges, above at note 60, 1293 as followed up, among others, by Reichman and Uhlir, and by Rai, Reichman, Uhlir and Crossman, both above note 53.

123 One recent example would be the decision by European Court 14 July 2011 (First Chamber), case C-46/10, Viking Gas A/S v Kosan Gas A/S, "gas bottles", concerning the issue whether the sale of a gas bottle intended for refilling triggers exhaustion. 
province there are transactions which impact not only on the goods or services provided, but also on the IP incorporated in them. Typically this is the case of dealings between the rightholder and the end user concerning copyright or data-base protected entities: software license agreements, contracts providing for access to data bases, music store delivery of music 'tracks' or subscriptions providing for music streaming, for a price, for free or by means of that hybrid, two-sided market, form which links delivery of content to exposure to advertising. In all these regards both literature and case law have taken off. ${ }^{124}$

This development is very much welcome in the perspective of bringing IP transactions up to date in a digital context. Indeed, the internet is, among other things, a machine for the exchange of IP-incorporating goods and services.

However, there is a whole area which should not escape our attention. Reference is here made to the transactions which may deal with IP rights or with goods and services incorporating IP and which may take place over the net, and still are neither contracts, nor agreements, nor otherwise contractual arrangements. These transactions may be referred to in several ways: acts which are non-contractual, obligations arising out of acts which are non-contractual or, resorting to a probably more selfexplanatory and possibly customary locution, 'unilateral acts'. ${ }^{125}$

The reason why the legal artefacts we label as 'unilateral acts' are important in the current landscape of IP are the same as why they are comparatively neglected. Usually the attention, both of private players and of scholars, is drawn towards price-based market exchanges concerning IP or IP-incorporating goods or services, which take place over the net. However, the metrics indicate that this is but a fraction of the transactions over IP or IP-incorporating goods or services taking place over the net. The bulk is indeed coming from a different source: cooperation over the net, making available for free the results of cooperation or of individual contributions, again over the net. This is so for a very simple reason: the short route is taking over the long route. As earlier indicated, the stage scenario has indeed changed: social sharing enters; business recedes. We cannot fail to recognize this shift: however

124 As an early example see I. Winternitz, Electronic Publishing Agreements, Oxford, (2000).

125 As a civil lawyer, I find it quite difficult to find an analogy between the notion of 'unilateral act' and an equivalent concept under common law. In this regard I find the notion of unilateral contracts (on which F. Kessler and G. Gilmore, Contracts. Cases and Materials, Little, Brown and Co (1974) rather confusing. 
successful may a re-design of IP rights turn out to be, it still would be to a large extent vain, if the tools required to carry out transactions dealing with them or with goods incorporating them were not up to the task.

\section{B. Three Structural Features of the Second Variety of Digital Licensing}

The time has therefore come to have a closer look at the legal contours of the transactions which are taking place along the short route and are substantiating sharing.

A good starting point for doing this is to consider what we earlier described as the second variety of digital licensing. It is true that not all forms of sharing take place under CC, OKF or GPL conditions; but the terms and conditions stipulated by these very popular transactional tools may give a good approximation. This is confirmed by the metrics (over 400 million works are reported to be licensed under CC) $)^{126}$ and by the qualitative data, including the 'virality' feature which would appear apt to push upwards the rate of adoption of copyleft licensing.

On this basis, we should go back to the contrast we instituted between classic licensing and the first variety of digital licensing on the one side and the second variety of digital licensing on the other side. ${ }^{127}$

In this connection we shall consider three features. The first one, (a), has to do with the social determinants of the phenomenon; the second and the third one, (b) and (c), with their technological determinants. ${ }^{128}$ In going through the exercise I will put on the lenses of Italian municipal law; but, in doing so, I will not fail to eventually ask myself whether this perspective is apt and appropriate in connection with the digital and global features of the phenomenon we are dealing with here. Anyhow, let's get down to the mechanics of the business at hand first.

a. (Lack of) consideration. Typically classical licensing and the first variety of digital licensing consists of price-based market transactions which provide for payment of consideration: a royalty or the payment of some other form of price or fee. This feature accounts for the fact that normally - if not always $-{ }^{129}$ these

126 See <http://wiki.creativecommons.org/Metrics> accessed 5 January 2014.

127 Section III.B

128 See respectively sections III.D and III.C.

129 Consideration may occasionally lack in trade mark licenses [M. S. Spolidoro, 'La legittimazione attiva dei licenziatari dei diritti di proprietà industriale' (2006) AIDA 219] and in connection with the so-called releases, i.e. 
licenses come in the form of a contractual agreement. In contrast, FOSS, CC and other alternative licensing forms typically do not contemplate payment of sums; they are tools either for making available digital resources for free over the net or to contributing small grains of creativity towards some cooperative enterprise. ${ }^{130}$ This characterization goes a long way to account for the fact that normally these licenses do not come in the form of contractual arrangements, or agreements, but rather in the form of unilateral acts. Whether this act is visualized as a unilateral act, as a license, or a waiver, depends on a number of factors, which vary in the different legal systems. A common denominator is at work here, however: the license is based on a unilateral act from licensor to the benefit of the licensee. ${ }^{131}$

b. Parties. In the second variety of digital licensing, licensor authorizes, under the terms and conditions of the license, not only the initial licensee, but also all the other third parties who may at some point of the chain obtain a digital copy of the licensed content or work. Characteristically, licensor directly authorizes whomever may happen to re-use a digital copy disseminated by a licensee in

unilateral authorizations to use images and copyrighted work [on which see G. Resta, 'I diritti della personalità' in G. Alpa and G. Resta, Le persone e la famiglia, 1 Le persone fisiche e $i$ diritti della personalità in Trattato di diritto civile diretto da R. Sacco, Torino, (2006), 361, 639 and I. Garaci, 'I contratti per lo sfruttamento del nome e dell'immagine. Parte generale' in A.M. Gambino (ed.), I contratti di pubblicità e di sponsorizzazione, Torino, (2012), 111, 116]. For a very similar analysis under UK and US law see P. Johnson, "Dedicating" Copyright to the Public Domain', 71 Modern Law Review (2008), 588, 604.

${ }_{130}$ Section III.D. It is true that a significant number of CC-licensed works (books, CDs, DVDs and the like) are sold; and that likewise GPL-software is often sold for a price. I suggest that this fact does not detract from the current analysis, as whatever price is paid is in consideration for the (tangible or intangible) copy obtained by purchaser; but the transaction does not prevent the receiving party from engaging in downstream dissemination, as long as the terms and conditions of the license are respected. This "dual" feature of open digital licensing deserves however greater attention than possible in the current context. Another issue which deserves additional thought is that licensee's personal data might be made available to licensor as an incident of the transaction (or rather: of the "code" under which the transaction takes place); at some point we should ask whether this sort of exchange (between the "free" license and the surrender of valuable data) may amount to a consideration of sorts. I am indebted for raising the issues tucked away in this footnote to J.C. De Martin and Raimondo Jemma respectively.

131 Or, rather, the licensees: see under b. below. 
accordance with license terms and conditions, rather than authorizing licensee to further sublicense the copies she may have been authorized to re-use. ${ }^{132}$

Technologically, this feature is made possible ${ }^{133}$ by the fact that the initially licensed file, which can be multiplied into innumerable perfect copies as it is digitally disseminated across digital networks, carries with it metadata; and that these metadata in turn point to the automatically reprocessable metadata built in the license under which the file is released. We come to realize this if we look again at the 'open definition': there the quality of being 'open' is referred to as 'a piece of data or content', which is defined as open 'if anyone is free to use, re-use or distribute it'. ${ }^{134}$ Thus, it is the digital resource which is free, that is, under the terms and conditions of the license; and this freedom applies to the same resource in connection with the fact that the resource as such is obtained, regardless of the identity of the person or entity that has been the prior, intermediate link to deliver the resource and of the person or identity that receives it. I will later refer in greater detail to 'travelling' clauses and waivers. At this stage I will confine myself to stating that the terms and conditions of the license 'travel' in the sense that, as the (non-rival) digital resource is multiplied by being made available across digital networks, the persons or entities at the receiving end are authorized to re-use the same resource under the terms and conditions which are attached to it through the metadata which accompany it.

From a legal viewpoint, it should be underlined that this approach is based on a direct license between the rightholder/ licensor and the additional, downstream licensees. This direct license, which we may visualize as per saltum as it jumps from licensor to each downstream licensee 'over the shoulders' of the intermediate licensee through which the digital file or fragment has been obtained, it is in stark contrast to what happens in classical licenses and in the first, proprietary variety of digital licensing.

In classical licensing, the possibility of the licensing of additional, downstream licensees is not altogether ruled out. But it must rely either on a direct contact between licensor and the additional licensee or licensees, or, in the alternative, on a chain of

132 See e.g. Art. 8 CCBY.

133 Or, indeed, determined: I suspect that my account incorporates some dose of technological determinism which at some point I should come to grips with. 134 See http://opendefinition.org/ (bold added). 
authorizations, which then takes the form of sublicensing from licensee to downstream sublicensees rather than of direct licensing from licensor to additional licensees. ${ }^{135}$ Therefore, sublicensing must be contemplated and agreed to in advance in the original arrangements between licensor and the first licensee. Being the result of a chain of authorizations, the title of the sublicensee depends on the title of sublicensor; should the original license be terminated, also the sublicense would be automatically lose its very basis.

In proprietary digital licensing, sublicensing is always contractually prohibited. The same prohibition applies to assignments. Third parties who obtain the digital goods from licensee are infringers; full stop. ${ }^{136}$

c. Subject matter. As a rule the subject matter of classic IP licensing is a specific IPR, be it a trademark, a patent, a copyright, or another IP-protected entity. It is not unusual for the license to extend to larger units. It may encompass 'packages', that is different IP rights: thus a patent license may be accompanied by a know-how license; a licensee may be authorized to use patentee's trademark on the patent incorporating products; and so on. Also portfolios, rather than individual IP rights, may be licensed. Actually, this is common practice in some sectors, particularly in patent licensing, where the licensing of entire patent portfolios has become current practice.

In the second variety of digital licensing, the direct authorization from licensor to additional, downstream licensees extends to smaller units: also to any fragment of the digital copy which is re-used by licensee, ${ }^{137}$ except in cases where only the re-use of the digital asset in unchanged form is allowed. Indeed, only entities which would not attract protection are not encompassed by the

135 On sublicensing see P. Rescigno, 'Contratto (in generale)'(1988) Enc. Giur. Treccani vol. IX, 30. See also for extensive reference to case law A. G. Diana, Il subcontratto, Torino, (2003) and the wide theoretical framework sketched by C. M. Bianca, Diritto civile, III, Il contratto, Milano, (2000), 728.

136 This at least in the intention of licensor; for an alternative view, reached by European case law, see EU Court 3 July 2012 (Grand Chamber), case C-128/11, Used Soft v Oracle International Corp., 'Used Soft'. For a thoughtful commentary of this case see R. Rivaro, 'L'applicazione del principio di esaurimento alla distribuzione digitale dei contenuti protetti' in Giur. Comm. I, (2014) forthcoming.

137 See Sec. 2(a)(1)(A) CCBY. 
terms and conditions and the license and therefore are not authorized, for the simple reason that their re-use does not require authorization. ${ }^{138}$

\section{From Contract to Unilateral Acts}

We may now finally come to grips with the legal segment of the analysis. The economic rationale at the basis of the second variety of licensing also helps to understand the reason why the tool of election used by licensors to engage in a transaction - or, more to the point, a series of transactions - with licensee(s) is not a bilateral agreement, or contract, but a unilateral act.

Earlier, we noted that digital licenses of the second variety, in opposition to all other licenses, do not contemplate royalties, fees, a price or consideration for the use of IP. We are in a position now to see why this is so: the lack of consideration does not indicate that the transaction has a purely altruistic and other-regarding basis but that it is not a price-based market exchange, or, may be more accurately, that it is a non-market transaction which is part and parcel of an economic and social production mode based on cooperation and sharing.

This fact goes a long way to explain why a contract is not strictly necessary here. Of course, if licensees were to undertake to make a payment; or even were to make a payment, the combination of licensor's grant and of licensee's payment would inevitably amount to a contract. But this is not the case here, where by definition no money changes hands. We should pause for a moment to look at the implication of this quite extraordinary - feature.

To begin with, licenses of the second variety are 'non-transactional'. Even when the digital resource is made available over the net, the grant of the license does not entail any form of acceptance, including the otherwise usual 'clicking' normally required of licensee to indicate acceptance by the licensee herself of the terms and conditions of the license. The digital resource automatically comes with the terms and conditions of re-use attached, by the combination of metadata the resource carries along within itself and the automatically reprocessable

138 Of course, in all forms of licensing the authorization to use the entire entity encompasses the right to use only parts of it. What is characteristic of the second variety of licensing is that the authorization extends to the re-use of the fragment as such, and not as a component of the entire work. 
metadata built-in within the license. A 'non-transactional' mode is seen as the best way to foster the widest dissemination possible of the digital resource.

There is an additional ground why digital licenses of the second variety tend to avoid contract and to favor unilateral acts. The same clause binds the initial licensee as any subsequent licensee; the same waiver benefits the initial licensee and the subsequent ones. This effect, which is a necessary implication of open licenses, ${ }^{139}$ is best reached by having the clause and the waiver spelled out once and for all by licensor by way of an unilateral act (i.e. by reference to the original license terms) and of incorporation by reference in the metadata which travel along with each digital file or fragment of file. It is important to spell out why in this connection a contract would not do the trick. There are two reasons why contract turns out not to be the appropriate tool to reach this end. Only the second is really compelling.

The first difficulty which comes to the mind is located at the receiving end. From a contractual perspective, one may begin to wonder how we may possibly have a meeting of the minds when downstream licensees, incorporating the digital fragment in their own product or service, may hardly be deemed to be 'consenting' to the terms and conditions of the license. This is however not necessarily a hurdle which cannot be overcome: legal systems, including the Italian one, have long devised a mechanism whereby, where the transaction is only liable to benefit the other party, the offeree, without entailing burdens to the same, a contract may still come into being where the same offeree is made aware of the offer and is in a condition to refuse it: see Art. 1333 of the Italian Civil Code. ${ }^{140}$ The re-user of the digital file (or of the digital fragment) to which travelling terms and conditions are attached by dint of metadata may hardly be deemed to be refusing them. Therefore, if we confine ourselves to looking at the receiving end, we may still think up of ways to infer some form of consent, even though this may turn out to be rather fictive or fictional. So this hurdle to devising a contractual relationship may still be overcome.

139 As explained at section VII.B, lett. a. (it should be noted that this feature is bound, however, to lead to the difficulties examined in section VII).

140 It has been noted that Art. 1333 is intended to expand the notion of contract in a way which may be reconciled with the assumption ('dogma') whereby no changes into the economic sphere of individuals or entities may be affected without their consent: see in this connection L. Bigliazzi-Geri, U. Breccia, F. Donato Busnelli and U. Natoli, Diritto civile, 3. Obbligazioni e contratti (1989), 528. 
However, the real difficulty is to be found, maybe rather surprisingly, at the sending end. As digital files and fragments travel around the cyberspace, it becomes rather difficult - if not impossible - to assume that there is a meeting of the minds between a licensor, who does not know or even imagine (and cannot even find out, even if she tried) the identity of the person or entity that happens to obtain a digital copy of the file or of the fragment (the downstream licensee), on the one side, and the same licensee, on the other side. It is true that at the turn of the last century contract law successfully faced another situation where offeror had no idea of the identity of her counterparties; and devised the legal device of the offer to the public (in Italy: Art. 1336 of the Italian Civil Code) to deal with it. It is well known that this development was triggered by the diffusion of the Automaten, the automatic machines which originally dispensed tickets and goodies against cash and was later extended to Automated Teller Machines, which effect the exchange of cash against debt. ${ }^{141}$ However even the expansionary potential of contract law shown at this junction has its outer boundaries: if we may plausibly conceive of a contract between the comptroller of the automated machine (X) and the (unidentified) user of the same (Y1), it is submitted that it is much more difficult to conceive of a corresponding mechanism whereby a contractual exchange may be deemed to take place further down the line, between the same $\mathbf{X}$ on the one side and Y2, Y3 and so forth on the other, once the tickets or the goods exit the automated machine and travel around out of control of their initial seller. ${ }^{142}$

I suggest that this difficulty may be greatly mitigated, or even overcome, when resort is made to the tool which in market-exchange based economies has hitherto been the lesser brother of contract, namely the legal artefact we designate as unilateral act. While this instrument appeared to be recessive in systems which took exchange as the central paradigm of economic activity and built around it the legal framework for private transactions, it may well be that the tide is now turning as the formerly dominant price-based market exchange is being complemented

141 For a discussion of this development see C. M. Bianca, Diritto civile, III, Il contratto quoted above at note 135, 247.

142 A possible - if convoluted and probably implausible - way out is offered however by the route followed in figuring out a contractual relationship between the software holder on the one side and the end-user, who obtains the physical copy through an intermediary, in shrink-wrap cases: see in US case law ProCD, Inc. $v$ Zeidenberg, 86 F.3d 1447 ( $7^{\text {th }}$ Cir. 1996); for further references see my 'Software e limitazioni delle utilizzazioni del licenziatario', AIDA (2004), 358, 370. 
and at times replaced by the transactions characteristic of the new sharing economy. ${ }^{143}$ Both giving away for free one's music, photos or audiovisuals (gift) and sharing do not require that any given contribution is matched by a flow of resources going in the opposite direction; in particular, the magic of sharing operates when many discrete contributions seamlessly complement each other to bring about private and public goods, or a mix of them, which would not be available without the combination of these discrete contributions and which ultimately could make the contributor richer rather than poorer than at the beginning of the cycle. In such a context, it may well be that the time has come for unilateral acts, which offer the nuts and bolts for building a framework of contributions without immediate reciprocation, to take the floor.

Coming back from metaphysic to the microphysics of private transactions, it would seem that the tool provided by unilateral acts may do the trick much better than contract in accounting for the functioning of the second variety of digital licenses in general and specifically for the institution of a legal relationship between licensor and licensees by way of what I earlier (in section VII.B, lett. a.) called direct licensing.

Indeed, in our legal system, before a contract becomes effective, a not insubstantial number of requirements has to be met: offeree must have had a chance to refuse the offer; therefore he must have been put in a position to be aware of it; plus, the offeror must have made the offer to begin with, which is an occurrence which can be easily taken for granted in the bricks-and-mortar word, ${ }^{144}$ but may be much more difficult to conceive of in a digital world where digital files and fragments are sloshing around the net.

In this specific connection, the legal framework for unilateral acts (at least in our legal system) is much less demanding. It is true that in principle also unilateral acts take effect only from the moment when they come to the knowledge of the person or entity they are intended for, Art. 1334 of the Italian Civil Code. However, our legal system provides by way of exception for several subsets of unilateral acts where the effect of the act itself is immediate and does not require at all knowledge by a specific addressee (or addressees). This is the case of unilateral promises, Arts. 1987 ff. of the Italian Civil Code, which include, under Art. 1989 ff., promises to the public, which are deemed effective and binding on the promisor at the very moment at which the promise is made public. ${ }^{145}$ The

143 See above section III.

144 And here might lay the difference to shrink-wrap cases.

145 See Bianca, quoted above at note 135, 250. 
same rule as to the time in which the obligation sets in applies to waivers: which are believed to be unilateral acts which are effective before and even without being brought to notice of the party - or parties - which may ultimately benefit from them. ${ }^{146}$ It seems to me that promises to the public and waivers, or, to the extent admissible, ${ }^{147}$ other unilateral acts may form a quite reliable basis for direct licensing: they are binding on the rightholder-licensor from the moment the terms and conditions are promulgated by the same. As the digital file (or fragment) carries with it the same terms and conditions, whoever re-uses the same digital file (or fragment) becomes a licensee, in spite of the fact that she has no direct contractual relationship (and certainly has had no dealing) with the licensor.

This does not mean that the route of unilateral acts is there just waiting for us to leisurely embark upon it and that taking this route is sufficient to overcome all the difficulties which typically are to be met by resorting to contract. The fact is that, while contracts are large, well-explored auto-routes, with which we are familiar after a long, long time of experience, unilateral acts still are, in our systems, including the Italian one, minor byways, not much frequented and possibly in a state of disrepair.

Not only this; it is also quite clear that the legal system, or the way past commentators have interpreted it, incorporates a certain amount of suspicion towards contract's lesser brother, the unilateral act. Thus, it was held, particularly in the past, that unilateral acts are typical, i.e. admissible only to the extent specifically provided for by the law, ${ }^{148}$ in contrast to the rule provided in connection with contracts, which are declared binding and valid also when not specifically corresponding to a legal 'type'. ${ }^{149}$

In my opinion these are not really serious obstacles after all, however. First of all I do not see insurmountable problems in construing digital licenses of the second variety as promises to the public, waivers or a combination of the two; second, I am in good company when I say that the idea that unilateral acts are restricted by a principle of 'typicity' is

146 See in this connection Bigliazzi-Geri, Breccia, Busnelli and Natoli, quoted above at note 140, 553.

147 Below note 148 and accompanying text.

148 For references to this opinion - and criticism against it - see BigliazziGeri, Breccia, Busnelli and Natoli, quoted above at note 140, 518.

149 As long as they are directed towards interests which are worth protecting by the legal system: Art. 1322 of the Italian Civil Code. 
just a legacy of olden times, ${ }^{150}$ which, if I may so add, has no legitimacy now that the market exchange is increasingly complemented - and at times replaced - by cooperation and sharing. ${ }^{151}$

\section{Unilateral Acts: Travelling Clauses, Travelling Waivers, Stability and Non-Revocability}

Indeed, reference to the conceptual and legal framework provided by unilateral acts helps to deal with a number of the typical features of the second variety of digital licensing.

Some of these may turn out to be quite obvious at this juncture; particularly so in connection with the issues we looked at earlier. ${ }^{152}$ That no consideration is contemplated in exchange for a unilateral act is a truism; if it was contemplated, there would be no unilateral act but rather an exchange, also a contract. As far as the parties are concerned, we just saw how direct licensing, while incompatible with contract, may find a reliable basis in a unilateral act.

This last remark should be expanded to further note the role played in this context by 'travelling clauses' and 'travelling waivers'. As re-users of any given digital file or fragment obtain it under the terms and conditions originally promulgated by licensor, they all have to abide by the same clauses of the license and may in turn benefit from the waivers made by licensor in the license. This phenomenon may give the impression that all the downstream licenses are governed by 'travelling clauses' and 'travelling waivers', except that in truth what actually 'travels' is not the clause or the waiver, but the digital file to which the terms and conditions are attached, so that each licensee is both obliged and benefited by terms, conditions and waivers which are the same for her as for all the other licensees.

While these remarks are - more or less obvious - corollaries and implications of the foregoing analysis, there are two points which deserve fresh attention.

1. Stability. What happens if the terms and conditions set by licensor $\mathbf{A}$ are complied with by licensee $\mathbf{B 2}$, who obtains the digital file or fragment through B1; but B1 herself does not, for whatever reason, comply with them? Granted that the license obtained by $\mathbf{B 1}$ is

150 See Bigliazzi-Geri, Breccia, Donato Busnelli and Natoli, quoted above at note 140, 518-9; 529; Bianca, quoted above at note 135, 260.

151 See section VII.B.

152 Ibid. 
terminated, and may be even automatically terminated; ${ }^{153}$ and granted that $\mathbf{B} \mathbf{1}$ is by definition an infringer a moment after termination, does this fact affect B2's position? If we were talking about a license contract, and if $\mathbf{B} \mathbf{2}$ accordingly were a sublicensee, the reply would be pretty straightforward: as B2's acts would be deprived of their legal basis, which is the continued existence of a valid grant between $\mathbf{A}$ and B1, then also B2's sublicense would be automatically terminated and $\mathbf{B} 2$ herself would be an infringer, even though an innocent one. ${ }^{154}$

This is not, however, what happens under digital licensing of the second variety if we see it with the lenses of unilateral acts rather than of contract in the light of Italian municipal law. In the unilateral grant perspective, each grant from $\mathbf{A}$ to $\mathbf{B 1}, \mathbf{B 2}, \mathbf{B 3}$ and so on is independent from the other. This is the beauty - and the resilience - of direct licensing. If $\mathbf{B} \mathbf{1}$ is in breach, his license is terminated and she is an infringer; but B2, who obtained title directly from A, may still continue under the umbrella of the license, that is, so long she complies for her own part with its terms and conditions.

153 Under Italian law automatic termination clauses would appear to be enforceable. For completeness sake, it should be kept in mind that there are theoretical reasons against this solution. Art. 1456 of the Italian Civil Code provides for 'automatic termination' in the event a term of the contract is not complied with. However, the same provision requires that the clause the breach of which triggers termination be specifically indicated; and requires the party not in default to give notice to the other party. So Art. 1456 would not appear to help much in this connection. However the case law indicates that the parties can agree that non-compliance with any term of the license is a defeating condition (condizione risolutiva) under Arts. 1355 ff. of the Italian Civil Code. The idea is resistible, as a condition is usually thought (and defined) as an occurrence or event, which conveys the idea that an agreement may be conditional on external events rather than behavior by one of the two parties. Nevertheless the case law is rather consistent in saying that yes, the parties may agree to that: see Cass. 24 November 2003, No 17859; 10 October 1993, No 10074; 8 August 1990, No 8051. A reply in the affirmative to the same question in connection with a GPL is to be found in Landgericht München 19 May 2004 (decree), H. Welte v S. Deutschland (2004) quoted above in note 40.

154 It may be of interest to note that 'innocent infringers' tend to crop up when the IP protected corpus mechanicum may travel in a way which is out of control of the original parties of the transaction (the IP holder and the purchaser of the IP-incorporating goods): see Canada Federal Court of Appeals 4 September 2002, Percy Schmeiser v Monsanto Canada Inc., in [2002] FCA 309. 
2. Non-Revocability. What if the license has no final term? In the Italian legal system, it is widely believed that contractual obligations cannot be perpetual. ${ }^{155}$ This opinion is highly questionable, as well as the corollary which is derived from it, whereby all contractual obligations are held to be necessarily and per se revocable.

If one assumes that a digital license of the second variety is best explained as a unilateral act rather than a contract, then it may well be that such a unilateral act turns out not to be subject to revocation. E.g. a waiver typically is not conceived as revocable, but rather as final. This is best explained by thinking about the rules applicable to so called releases, i.e. the authorizations given by rightholders, e.g. in connection with the incorporation into a movie of a given snapshot or a copyright-protected sentence to be incorporated in a movie. As it was noted a long time ago, ${ }^{156}$ all the movie industry would be built on quicksand, if the release were revocable; and the legal experience of over one century tells us this is not the case.

\section{E. An Interim Assessment}

Am I saying therefore that all is well and that we have found in unilateral acts the silver bullet? Not at all, actually. Short of the situations where the judge, Italian or otherwise, finds that the relevant connecting factors point to the applicability of Italian law to any given dispute concerning a digital license of the second variety, ${ }^{157}$ then the issues we have been looking at may or may not remain open, depending on the, from time to time, applicable law; which law may adopt either the rather convenient solutions I have been sketching out based on Italian law or alternative solutions, which may turn out to be as convenient or, on the contrary, less so or even frankly inconvenient. ${ }^{158} \mathrm{Be}$ that as it may, the conclusion is

155 For a review of the literature and of the case law see P. Gallo, Trattato del contratto, T. 2, Il contenuto. Gli effetti, Torino, (2010) 1247 and note 33.

156 By P. Vercellone, Il diritto sul proprio ritratto, Torino, (1959), 118. This argument has been reiterated, in recent times, in connection with releases concerning the portraits or names of individuals, also entities protected as personality rights, in the entertainment industry: see G. Resta, 'I diritti della personalità' quoted above at note 129, 632 .

157 Which is an issue not easy to sort out, anyhow.

158 A pretty clear analysis concerning common law jurisdictions is to be found in the very valuable essay by Johnson, quoted above at note 129, 605, 
hardly reassuring, given that any given digital file is bound to come through the peculiarity of direct licensing which we earlier discussed into the hands of ever so many downstream licensees, in settings which may point to the applicability of disparate laws and therefore generate diverging outcomes depending on the rules applicable in the different jurisdictions. The same multiplicity applies to the fragments which go into a larger work: imagine that a Wikipedia item results from contributions from persons resident in Italy, Nicaragua, the US and Ecuador, plus another handful of countries: which law is applicable?

\section{COMPLEMENTARITY OF RE-USES AND EX-ANTE UNPREDICTABILITY: THE LEGAL IMPLICATIONS}

After looking at the implications of the approach to exclusivity and to non-rivalry in production of digital resources adopted by digital licenses of the second variety, which is the technological and social basis for the legal features we discussed in sections VII.B-D, we should build on our findings in this connection and further explore the corollaries of the other technological determinants of digital resources: their complementarity in re-use and the ex ante unpredictability of the combinations these resources are amenable to.

\section{A. Complementarity in Action}

In this connection, we should first visualize the phenomenon. Imagine a value added product which combines first music made available under $\mathrm{CC}$; second, a data base right released under an Open Knowledge Foundation and, third, is run by means of open source software licensed under FOSS terms. This rather simple minded example may be further complicated in a number of ways; still it may be an interesting starting point to indicate how different digital inputs may go into a downstream product. The example shows a pretty normal occurrence: digital inputs tend to be highly complementary and in principle may easily be integrated from a technological viewpoint. In a sharing model, the ways into which these inputs may be integrated is not governed top-down;

convincingly arguing that, as far as the US, England and Wales, and Scotland laws are concerned, non-contractual licenses may be revoked at any time, under a requirement of sufficient notice and subject to various limitations, such as estoppel or personal bar. 
rather it happens bottom-up. Nobody collecting meteorological data sets is likely to imagine in advance that they may end up being fine-tuned to allow for the most accurate and adjustment-prone forecasts to be used by teams dedicated to the maintenance of oil rigs; but this is what happens in reality. ${ }^{159}$

Now let us stop for a moment to think about what happens when any given downstream product or service incorporates a very large number of inputs originating from a very large number of different licensors; let us also consider that most of the times the same downstream product or service in turn is the result of a combination of digital inputs which could not be anticipated in advance by the holders of the IP-protected assets which go into the combination. Indeed, if two digital inputs are governed by two different sets of terms and conditions, and these do not dovetail, then the admissibility of their joint re-use is called into question. More specifically, re-use is not authorized, and thus entails IP infringement, if the terms and conditions are incompatible; or is authorized on the more restrictive terms and conditions, if one set is more restrictive than the other, while not incompatible with it. Herein lies the difficulty which has been conceptualized by the literature as an issue of interoperability and may turn out to be much greater than one may imagine at first glance. Indeed, practitioners first and scholars later have noted that even licenses which broadly speaking would appear to be to a large extent reciprocally compatible do have clauses which do not perfectly dovetail. One good example of this phenomenon is the attribution clause, which entails slightly different requirements depending on the fact that CCBY or ODCBY applies.

Additional difficulties may arise: e.g. it is arguable that compliance with the two attribution clauses mentioned above requires that the credit given identifies within the downstream product or service the components respectively attributable to the two inputs incorporated in it. It is also arguable that this difficulty is enhanced rather than mitigated, when the combination specifically concerns data sets, in particular public sector information (PSI). It is not unlikely that the complementarity rate exhibited by PSI assets is even higher than that shown by music, test, audiovisual works and software. In other words it would appear that statistically it may be more likely that parts or fragments of PSI digital assets are combined and matched to form downstream products or

159 See Deloitte, Tech4i2, and Others, European Commission, Information Society and Media Directorate-General, POPSIS, Pricing of Public Information Sector Study' Summary Report quoted above at note 24, 16. 
services than it is the case in connection with other entities (text, music, audiovisual works, software) which are the object of digital licensing of the second variety. ${ }^{160}$

We might wonder whether these issues can be dealt with on the basis of our experience in 'classical' IP licensing. It is true that even there we frequently meet references to the phenomenon of 'stacking', which describes cases in which a downstream product requires authorization by two or more holders of IP. ${ }^{161}$ Still, there is a huge difference between the two phenomena - as we shall currently see.

\section{B. The Interoperability Conundrum}

Let us try to clarify the interoperability conundrum using as an example PSI licensing (the picture would not be much different if we looked at another specimen of digital licensing of the second variety). The rightholder/licensor is indicated as A; it authorizes B to re-use a discrete item of PSI it holds (PSI A) into B's downstream product or service (B d.). $\mathrm{C}$ may in turn incorporate (B d.) in her own downstream product or service (C d.). If she does so, she is re-using (B d.) under the terms of the license between B and C; as far as (PSI A) is concerned, however, C gets a direct authorization from $\mathrm{A}$, in spite of the fact that she has no contact with $\mathrm{A}$ itself. This last feature is clearly shown in the licensing terms under which CC licenses are used. See Art. 8, of CCBY; art. 4.8 OdBL v. 1.0. As we earlier noted, this feature is intrinsic of the mechanism adopted for the licensing of digital intangible copies, which may "travel" from their originator, $\mathrm{A}$, to a subsequent downstream user, $\mathrm{C}$, through the intermediate passage point of $\mathrm{B}$, without $\mathrm{A}$ and $\mathrm{C}$ ever coming into reciprocal contact. ${ }^{162}$ Does 'classical' IP licensing prepare us for this quite extraordinary - feature? Not at all. Rather, here we witness to a quite striking discontinuity. 163

Until we fail to unravel this basic difference, we are at a loss to explain what is the meaning of 'stacking' in digital and PSI licensing. In classic IP licensing, stacking means that under a given set of circumstances (e.g.

\footnotetext{
160 See however Lessig, Remix quoted above at note 27, 51.

161 The debate on this phenomenon was initiated with a different terminology (referring to patents 'on basic building blocks') by. Merges, above at note 60, 1341.

162 See above,section VII.B.

163 Except when we take into consideration licensing of entities which may be self-replicating, as software and DNA-information, which may in this connection be considered as a bridge between "classical" and PSI licensing.
} 
partly overlapping patents) a licensee must obtain multiple authorizations before she is enabled to manufacture and sell her product. Stacking works differently in digital and PSI licensing. Here $\mathrm{C}$ incorporates in (C d.) her own value added, on top of (B d.); but, as also a fragment of (PSI $\mathrm{A}$ ) is incorporated in (B d.), she is authorized to include that digital input only if and to the extent she complies with both the terms of the authorization by $\mathrm{B}$, with whom $\mathrm{C}$ has had dealings, and by $\mathrm{A}$, with whom she has had no dealing at all. As a rule, the contact between $\mathrm{A}$ and $\mathrm{C}$ is instituted by means of digital networks; the work, the content, the fragment of the same carry with them the terms of conditions for re-use, i.e. the license, or at least reference to them; meta data take the place of dealings between $\mathrm{A}$ and $\mathrm{C}$, even though $\mathrm{C}$ gets a direct license from $\mathrm{A}$. In this latter perspective, 'stacking' describes the phenomenon whereby the conditions for re-use of (PSI A) travel with the digital input, so that non-compliance with these latter terms by $\mathrm{C}$ would mean infringement of A's rights by the same C; and they are therefore added ('stacked') over the conditions for re-use agreed between $\mathrm{C}$ and $\mathrm{B}$, which may - or may not - dovetail with the former.

We earlier noted that the existence of these sorts of 'travelling clauses', which spell out the obligations which licensee has to comply with if her re-use is to be lawful rather than infringing, is a crucial feature of digital licensing of the second variety and a necessary incident of the non-rivalry of digital resources. It should now be added that reference to travelling clauses or obligations in the plural is explained by another character of digital inputs, which, as indicated, not only are non-rival in production but exhibit a strong complementarity. As $\mathrm{C}$ may well incorporate the inputs coming from $\mathrm{A}, \mathrm{A} 1$ and so on and the inputs coming from $\mathrm{B}, \mathrm{B} 1$, it is likely that she is bound to simultaneous compliance with different sets of 'travelling clauses'.

Should we think that this elementary situation is not intricate enough, we can complicate it as much as we like just by turning our attention to licensor. Let us assume that licensor 'waives' her rights in some regard, as it may be when the licensed content incorporates data-base rights. A similar occurrence has been noted where licensor A may wish to insert a viral share-alike feature in its licensed PSI, but at the same time she waives it for certain classes of derivative content. Here the question is: does the waiver 'travel' further downstream when licensee incorporates A's fragment in her own product or service (B d.)? In accordance with the previous analysis, the reply should be in the affirmative. Therefore we also have 'travelling waivers' making the landscape of digital licensing of the second variety more diverse. The landscape gets even more complicated, when we think that A may wish that also B applies the same 
waiver, to avoid that the re-use of her initial contribution is blocked downstream, either by data-base rights or by the viral feature. If this wish takes the form of an obligation on the part of B to adopt the same waiver, a 'travelling waiver' (from licensor) is then combined with a 'travelling obligation to waive' (on licensee as a candidate to become a licensor).

Now we may come back to the earlier question whether classic IP licensing prepares us for any of this. The reply is clearly in the negative. Indeed, digital licensing of the second variety is based on authorizations structured in an automated way in such a manner as to enable licensor to directly authorize re-user even without having a direct dealing with her.

Chains of authorizations are not unknown to classic IP licensing; but there they take the starkly different route of sublicenses, whereby licensor A enables B not only to exploit directly the IP but also to authorize $\mathrm{C}$ (and possibly $\mathrm{C} 1, \mathrm{C} 2$, etc.) to exploit the same. Thus the question here is not one of 'travelling' - and potentially mutually incompatible - obligations; but of derivative compliance. ${ }^{164} \mathrm{~B}$ must make sure that she binds $\mathrm{C}$ (and, if applicable, C1, C2, etc.) to the same obligations as she has undertaken towards A; should $\mathrm{C}$ fail to comply, both $\mathrm{C}$ and $\mathrm{B}$ would simultaneously be infringing A's IP rights (and B might have recourse against $\mathrm{C}$ to be held harmless of the ensuing loss).

To cut a long story short: 'classical' sublicensing is a one-way route; digital licensing of the second variety in connection with downstream products which incorporate complementary digital inputs is a maze of criss-crossing avenues. This is explained by the fact that sublicensor sublicenses the same IP as licensor licenses to sublicensor; whereas digital licensing of the second variety concerns multiple digital inputs, which are multiplied as they are re-used and carry with them the travelling clauses and obligations which concern each of them.

\section{Complementarity of Re-uses and the Design of the Rules on Interoperability}

What is then the impact of legal rules on this conundrum? We remarked earlier that legal rules do have an impact on the governance of the legal implications of non-rivalry of digital resources, except that the multiplicity of legal systems called to deal with them may lead to diverging

164 As noted earlier, a situation similar to the one taking place in digital licensing of the second variety may occur when licensing concerns derivative patents, whereby $\mathrm{C}$, in order to obtain a license from $\mathrm{B}$, needs to obtain authorization both by B and from A, whose upstream patent is included in B's derivative patent. This is a rare occurrence, though. 
outcomes and to a very large risk of legal uncertainty, which cannot be remedied as long as we stick to the idea that applicable rules are bound to be municipal and selected in accordance with traditional conflict of laws principles. Here the difficulties are created by the complementarity and $e x$ ante unpredictability of the combination of digital inputs and accordingly take a different shape.

Indeed, the goal of facilitating the possibility of the creation of downstream products and services aggregating different digital inputs may best approximated by the adoption of rules favoring the standardization and interoperability of licensing terms. In this connection standardization promotes the adoption of uniform sets of rules applicable to the different digital inputs which may, by way of decentralized decisions by re-users, go into the creation of a downstream product or service. Standardization by definition avoids the compatibility problems earlier envisaged. Indeed, if $\mathrm{C}$ incorporates digital inputs coming from $\mathrm{A}$ and $\mathrm{B}$ and these carry with them 'travelling' clauses and waivers belonging to a uniform set of licensing terms and conditions, no issue of simultaneous compliance may by definition arise.

A comparable outcome may be reached by a different route, though. Even terms and conditions which are not uniform may be interoperable; interoperability means that, while terms and conditions are not identical, they are not incompatible. ${ }^{165}$

In principle, devising and adopting standardized or interoperable sets of licensing terms is a matter which is best left into the hands of private players. Sovereigns may contribute to the task at the margin, by making the chances of success of private ordering greater. This is done on the positive side by fostering and promoting cooperation among stakeholders and assisting in the emergence of communities engaged in the creation of a sort of lex communitaria, which might be seen as a present day parallel to the emergence of the lex mercatoria which came to prevail in the later Middle Ages when municipalities and cross-border trade flourished. The components of this body of law may be gleaned, considering that legal systems should favor processes of delocalization, whereby the licensor/ licensee relationship should to the extent possible be governed by rules which are not nationally rooted but rely on the practices and perceptions of the community to which re-users belong. It should be underlined that this idea does not link back to ideas of independence of the cyberspace

165 See in this connection Palfrey and Gasser, above at note 116. 
from ancient regulators, ${ }^{166}$ which obtained some popularity a few decades ago but has in the meantime proved simplistic and inappropriate in view of the multiple interactions between virtual and bricks-and-mortar worlds. Rather the idea should link to successful experiments in selfregulation, where some experiences of homogeneous communities like commodities markets, stock exchanges and advertising come to mind, and the more recent experiment with the speedy and well-received dispute resolution mechanism concerning domain names ${ }^{167}$ would appear to provide a valuable template and starting point. ${ }^{168}$

The point here is not that sovereigns should keep their hands off; rather, that they should intervene by fostering the creation and the deployment of rules which are conducive to the cooperation between members of a community in order to optimize the benefits obtained by products and services which show a high rate of positive externalities. This new role may be played in the designing of an appropriate dispute resolution mechanism, to begin with; and might extend to the creation of 'black' or (better) 'gray lists', indicating which license clauses may hinder or restrict interoperability. ${ }^{169}$

There is also a negative side to sovereigns' task in this connection. Legal systems should to the extent possible refrain from adopting top-down national templates for licensing terms and conditions. This is a temptation which has unfortunately proved almost irresistible in the field of PSI, which is of crucial importance for the growth of value added digital products and services as it provides veritable minefields of raw data crying to be incorporated downstream.

Nominally, the rationale for adopting national rules, rooted in the specifics of a given legal system, links back to the fact that the relevant PSI was created and organized by a given public sector public sector information holding entity (PSIH), which is based in a specific jurisdiction, so that it would at first blush appear that it stands to reason that

166 As proposed by Johnson and Post, above at note 109 see also G. Teubner, "Global Bukovina": Legal Pluralism in the World Society' in G. Teubner (ed.), Global Law Without a State (Aldershot, Brookfield, U.S.A., Singapore, Sidney, (1997), 16.

${ }_{167}$ On the UDPR see F. M. Abbott, T. Cottier and F. Gurry, International Intellectual Property in an Integrated World Economy, Austin, Boston, (2007), 394.

168 For a similar approach see Metzger, quoted above at note 21, 365.

169 The task is not an easy one. For instance, the Commission Decisions 2011/833/EU of 12 December 2011 on the re-use of Commission information, in OJ 14 December 2011, L 330/39, falls short of the 'wish list' advocated here on most accounts.

Columns Design XML Ltd / Job: Drahos-Kritika_Essays_on_Intellectual_Property-x / Division: 06-ch6_tracked /Pg. Position: 68 / Date: 
the PSIH acquires rights and undertakes obligations on the basis of its own legal system also as far as the dissemination of PSI is concerned. However, this argument does not survive scrutiny when one considers that even national sovereigns have an interest in fostering cooperation in the exploitation of a non-rival resource showing a high degree of complementarity, without regard to the fact that the candidate digital input is foreign or national; and one keeps in mind that national licenses do not mix easily. ${ }^{170}$ Moreover, in the EU perspective the positive obligation of Member States to contribute to the creation of the internal market should play an important role. In any event the fact that a given data set has a given national 'entry point', e.g. data collected by a British PSIH, should not unduly influence the rules by which it is governed at some later stage of its - in all likelihood quite roundabout - life cycle, any more than any given car first put into circulation in the UK should be governed by British law even when it travels abroad.

\section{DIGITAL LICENSING AND THE QUEST FOR GLOBAL RULES}

In a nutshell: I argued that the most relevant private law issues to be faced by digital licenses of the second variety are best understood as implications of the approach adopted by them towards exclusivity and non-rivalry in production on the one side and of the complementarity in re-use of the digital inputs made available through them on the other side.

We have also seen (in section VII) that digital licenses of the second variety are unilateral acts, rather than contracts; that the relationship between the one licensor and the many licensees does not amount to a sublicense but to a direct license and that the license itself may concern fragments of the digital resource. We have seen how these features, while linking back to the social basis of on line cooperation and specifically to sharing and peer production (section III), turn out to be the - unavoidable? - outcome of the technological determinants of this mode of

170 For references in demonstrating this - quite self-evident - point see my Public Sector Information as Open Data quoted above at note 22, section III. The point should also be added that interoperability requires that automatically reprocessable metadata are built in licenses, including their semantic representation in accordance with the Linked Data approach, which is a task which probably would be hardly manageable by the legislators of 28 Member States and is best undertaken by private ordering having a global dimension.

Column\$ Design XML Ltd / Job: Drahos-Kritika_Essays_on_Intellectual_Property-x / Division: 06-ch6_tracked /Pg. Position: 69 / Date: 
creativity. Indeed, non-rival digital resources automatically coming with the terms and conditions of their re-use attached would not be capable of pulling the trigger of contract, while they are perfectly able to do so with the trigger of unilateral acts (section VII.C). These legal artefacts, while comparatively unexplored in societies building their activity on pricebased market exchanges, have a magic of their own; they also happen here to be able to contribute to the stability and non-revocability of on line transactions (section VII.D), as it should be if we do not want our digital castles to be built on quicksand (and platforms renege on their promises).

Also the other dominant technological features of the digital licensing of the second variety - complementarity in re-use and ex ante unpredictability of the combinations of the digital resources - account for the issues of standardization and interoperability of terms and conditions (section VIII).

Legal rules applicable to digital licensing of the second variety ultimately concern online cooperation. As the net is everywhere and nowhere in particular, traditional conflict of laws analysis is at a loss to identify robust connecting factors (sections VII.E and VIII.A). If contributions from 100 countries go into a Wikipedia article, how on earth can we find what the closest connection is with one specific contribution to the exclusion of all others?

Therefore, while the analysis of digital licenses of the second variety has been conducted with the lenses of Italian law, it is submitted that any approach rooted in municipal law and in the process of choice among multiple municipal laws is doomed to failure in connection with online cooperation. In connection with market exchanges and contracts, choice of laws may still work: after all there is a place where the (albeit digital) goods or services are delivered or supplied; also payments (even though digital), end up in an account which is likely to be linked to some place of residence. For unilateral acts this is not necessarily true: online cooperation as a rule entails that thousands of 'small grains' of contribution come from everywhere to form a larger unit which in turn is accessible from everywhere; while in the past we might have had the illusion that the digital resource resulting from the manifold contributions still was located on a physical resource - the 'server' -, with cloud computing we have lost even that illusion.

The lesson of this exploration therefore is quite simple, if extraordinary: while contracts, even online contracts, may still be municipal, 
unilateral acts cannot be but global. It is at this junction that comparative law must plan for its demise and start to look at global law as its next mission. ${ }^{171}$

A similar lesson comes also from the exploration of the corollaries of standardization and interoperability (section VIII). Here the task of ancient sovereigns has again a global dimension: their intervention should be confined to supporting and fostering the emergence of selfregulation of private stakeholders via private ordering; and refrain from meddling.

It is submitted that ancient sovereigns will never do that, unless they are forced to do so.

\section{CONCLUDING REMARKS}

So, it turns out that, yes, indeed, we are witnessing a twilight of sorts of exclusivity in intellectual property, but only up to a point. First, networkdriven cooperation, based on the feature of digital resources which makes them non-rival (not only in consumption, but also) in production, seems to be displacing the incentive provided by exclusivity more in the field of creativity than of technological innovation, also, more in copyright-based than in patent-based areas; second, even in connection with creativity, the emergence of a new paradigm of creativity appears to be complementary, rather than alternative, to the continued role of more traditional ('legacy') businesses; third, exclusivity is still required even in connection with cooperation-based 'sharing' models, as it remains the basis for enforcing contractual stipulations ensuring downstream openness. Also in the field of technological innovation, however, the roughest edges of exclusivity seem to be tempered by a number of mechanisms, which go from the resort to liability (rather than property) rules to the reliance on private ordering. Even here straight exclusivity is apt to backfire.

While this analysis would seem to suggest a dichotomy between old and new business models, it turns out that both models are challenged digital platforms, i.e. by digital natives which appear poised to grab and swallow up entire markets on the wings of zero marginal costs and network externalities.

171 For an excellent treatment of the issue of integrating the global dimension of unilateral acts with the municipal character of the IPRs which are the subject matter of digital licenses of the second variety, also from the perspective of contractual licenses, see Metzger, quoted above at note 21, 364-6. 
The impact of digital technology - and in particular of the feature of digital resources, whereby these are non-rival only in production, but also in consumption - is not confined to intellectual property. In terms of private law also, the novel features of network-driven cooperation point to a replacement of the role of contracts by unilateral acts; and suggest a rethinking of this - once minor - star in the skies of private law as the avant-garde of a new global mode of pooling and exchanging digital resources. 